\title{
Development of an Acrylate Derivative Targeting the NLRP3 Inflammasome for the Treatment of Inflammatory Bowel Disease
}

DOI:

10.1021/acs.jmedchem.6b01624

\author{
Document Version \\ Accepted author manuscript
}

Link to publication record in Manchester Research Explorer

Citation for published version (APA):

Cocco, M., Pellegrini, C., Martínez Banaclocha, H., Giorgis, M., Marini, E., Costale, A., Miglio, G., Fornai, M., Antonioli, L., Lopez-Castejon, G., Tapia-Abellan, A., Angosto, D., Hafner-Bratkovi, I., Regazzoni, L., Blandizzi , C., Pelegrin, P., \& Bertinaria, M. (2017). Development of an Acrylate Derivative Targeting the NLRP3 Inflammasome for the Treatment of Inflammatory Bowel Disease. Journal of Medicinal Chemistry, 60(9).

https://doi.org/10.1021/acs.jmedchem.6b01624

Published in:

Journal of Medicinal Chemistry

\section{Citing this paper}

Please note that where the full-text provided on Manchester Research Explorer is the Author Accepted Manuscript or Proof version this may differ from the final Published version. If citing, it is advised that you check and use the publisher's definitive version.

\section{General rights}

Copyright and moral rights for the publications made accessible in the Research Explorer are retained by the authors and/or other copyright owners and it is a condition of accessing publications that users recognise and abide by the legal requirements associated with these rights.

\section{Takedown policy}

If you believe that this document breaches copyright please refer to the University of Manchester's Takedown Procedures [http://man.ac.uk/04Y6Bo] or contact uml.scholarlycommunications@manchester.ac.uk providing relevant details, so we can investigate your claim.

\section{OPEN ACCESS}


Journal of

Medicinal Chemistry

Subscriber access provided by The University of Manchester Library

Article

\section{Development of an Acrylate Derivative Targeting the NLRP3 Inflammasome for the Treatment of Inflammatory Bowel Disease}

Mattia Cocco, Carolina Pellegrini, Helios Martínez Banaclocha, Marta Giorgis, Elisabetta Marini, Annalisa Costale, Gianluca Miglio, Matteo Fornai, Luca Antonioli, Gloria Lopez-Castejon, Ana Tapia-Abellan, Diego Angosto, Iva Hafner-Bratkovi\#, Luca Regazzoni, Corrado Blandizzi, Pablo Pelegrin, and Massimo Bertinaria

J. Med. Chem., Just Accepted Manuscript • DOI: 10.1021/acs.jmedchem.6b01624 • Publication Date (Web): 14 Apr 2017

Downloaded from http://pubs.acs.org on April 21, 2017

\section{Just Accepted}

"Just Accepted" manuscripts have been peer-reviewed and accepted for publication. They are posted online prior to technical editing, formatting for publication and author proofing. The American Chemical Society provides "Just Accepted" as a free service to the research community to expedite the dissemination of scientific material as soon as possible after acceptance. "Just Accepted" manuscripts appear in full in PDF format accompanied by an HTML abstract. "Just Accepted" manuscripts have been fully peer reviewed, but should not be considered the official version of record. They are accessible to all readers and citable by the Digital Object Identifier (DOI®). "Just Accepted" is an optional service offered to authors. Therefore, the "Just Accepted" Web site may not include all articles that will be published in the journal. After a manuscript is technically edited and formatted, it will be removed from the "Just Accepted" Web site and published as an ASAP article. Note that technical editing may introduce minor changes to the manuscript text and/or graphics which could affect content, and all legal disclaimers and ethical guidelines that apply to the journal pertain. ACS cannot be held responsible for errors or consequences arising from the use of information contained in these "Just Accepted" manuscripts. 


\title{
Development of an Acrylate Derivative Targeting the NLRP3 In- flammasome for the Treatment of Inflammatory Bowel Disease.
}

\author{
Mattia Cocco,${ }^{\dagger \|}$ Carolina Pellegrini, ${ }^{\sharp}$, I Helios Martínez-Banaclocha, ${ }^{\ddagger}, \|$ Marta Giorgis, ${ }^{\dagger}$ Elisabetta
} Marini, ${ }^{\dagger}$ Annalisa Costale, ${ }^{\dagger}$ Gianluca Miglio, ${ }^{\dagger}$ Matteo Fornai, ${ }^{\#}$ Luca Antonioli, ${ }^{\#}$ Gloria López-Castejón, ${ }^{\S}$ Ana Tapia-Abellán, ${ }^{\star}$ Diego Angosto, ${ }^{*}$ Iva Hafner-Bratkovič, ${ }^{\natural}$ Luca Regazzoni, ${ }^{\Psi}$ Corrado Blandizzi, Pablo Pelegrín, ${ }^{\dagger, *}$ Massimo Bertinaria ${ }^{\dagger, *}$

$†$ †ipartimento di Scienza e Tecnologia del Farmaco, Università degli Studi di Torino, Via P. Giuria 9 - 10125 Torino, Italy. \#Department of Clinical and Experimental Medicine, University of Pisa, Via Roma 55 - 56126 Pisa, Italy.

$\S$ Faculty of Biology, Medicine and Health, The University of Manchester, R4.004 AV Hill Building, Oxford Rd, Manchester, UK.

\$Molecular Inflammation Group, Biomedical Research Institute of Murcia (IMIB-Arrixaca), University Clinical Hospital "Virgen de la Arrixaca", University of Murcia, Carretera Buenavista s/n, 30120, El Palmar, Murcia, Spain.

qDepartment of Synthetic Biology and Immunology, National Institute of Chemistry, Hajdrihova 19, SI-1000 Ljubljana, Slovenia

YDipartimento di Scienze Farmaceutiche, Università degli Studi di Milano, Via Mangiagalli 25, 20133 Milano, Italy.

KEYWORDS: NLRP3, Bioluminescence Resonance Energy Transfer assay, Pyroptosis, Inflammatory Bowel Disease, Acrylates.

ABSTRACT: Pharmacological inhibition of NLRP3 inflammasome activation may offer a new option in the treatment of Inflammatory Bowel Disease (IBD). In this work, we report the design, the synthesis, and the biological screening of a series of acrylate derivatives as NLRP3 inhibitors. The in vitro determination of reactivity, cytotoxicity, NLRP3 ATPase inhibition, and antipyroptotic properties allowed the selection of 11 (INF39), a non-toxic, irreversible NLRP3 inhibitor able to decrease interleukin-1 $\beta$ release from macrophages. Bioluminescence resonance energy transfer experiments proved that this compound was able to directly interfere with NLRP3 activation in cells. In vivo studies confirmed the ability of the selected lead to alleviate the effects of DNBSinduced colitis in rats after oral administration.

\section{INTRODUCTION}

Human inflammatory bowel diseases (IBD), the most important entities being ulcerative colitis and Crohn's disease, are chronic relapsing-remitting inflammatory conditions that result from a chronic dysregulation of the mucosal immune system in the gastrointestinal tract. ${ }^{1}$ Ulcerative colitis is a recognized risk factor for colitis-associated colon cancer. ${ }^{2}$ In vivo models of colitis showed that a key role in the onset and maintenance of chronic inflammation is played by a multiprotein complex known as the nucleotidebinding oligomerization domain, leucine-rich repeat and pyrin domain containing protein 3 (NLRP3) inflammasome. ${ }^{3}$ NLRP3 inflammasome is a cytosolic complex involved in the production of pro-inflammatory cytokines such as interleukin (IL)-1 $\beta$ and IL18. NLRP3 inflammasome is formed by oligomers of NLRP3 that recruit via pyrin-pyrin homotypic interactions the adaptor protein apoptosis-associated speck-like protein containing a caspase recruitment domain (ASC). Then, ASC oligomerizes in filament-like structures that recruit and activate the pro-inflammatory caspase- $1 .{ }^{4-6}$ The NLRP3 inflammasome activation is tightly regulated and requires two different signals to exert its biological response: the first signal (priming) is provided by the activation of the Toll-like 
receptor-nuclear factor- $\kappa \mathrm{B}$ (TLR-NF- $\kappa \mathrm{B}$ ) pathway which upregulates the expression of NLRP3 and the inactive form of IL-1 $\beta$ (proIL-1 $\beta$ ); the second signal (activation and assembly) is triggered by different pathogen-associated molecular patterns (PAMPs) or damage-associated molecular patterns (DAMPs). ${ }^{7,8}$ After NLRP3 inflammasome is assembled and oligomerizes ASC, procaspase-1 is recruited and autocleaves itself releasing active caspase-1, which is the final effector in interleukin maturation and pyroptotic cell death. ${ }^{8}$ Therefore, NLRP3 is emerging as a promising target to develop novel and specific anti-inflammatory compounds. ${ }^{9,}{ }^{10}$ Indeed, although NLRP3 is considered a pivotal player in regulating the integrity of intestinal homeostasis, it also shapes innate immune responses against commensal bacteria, and its overactivation during intestinal inflammation is associated with a breakdown of the intestinal immune balance, with consequent detrimental effects for the host. ${ }^{11}$

Of note, current clinical evidence has documented an increased IL-1 $\beta$ secretion from colonic tissues and macrophages of IBD patients, these patterns being correlated with the severity of the disease, thus suggesting an involvement of inflammasome pathways in the pathogenesis of IBDs. ${ }^{12-14}$ Moreover, single nucleotide polymorphism in the regulatory region of NLRP3 gene has been associated with the susceptibility to Crohn's disease. ${ }^{15}$

In this setting, given the involvement of inflammasome pathways in the pathophysiology of intestinal inflammation, current research efforts are focusing on the potential therapeutic benefits, in terms of anti-inflammatory activity, resulting from the pharmacological blockade of NLRP3 inflammasome. The most explored strategies in the discovery of new experimental drugs targeting NLRP3 pathways in IBD are: (i) inhibition of activation of the transcription factor NF- $\mathrm{B}$; (ii) protection from mitochondrial damage; (iii) activation of Keap-1/ Nrf2 antioxidant pathway; (iv) inhibition of pro-caspase-1 cleavage through undefined interactions with NLRP3 inflammasome (Figure 1). ${ }^{16}$ Currently there are no specific NLRP3 inhibitors used in IBD therapy; to date few molecules acting at the aforementioned pathways have been studied (structures are summarized in Figure S1). None of the studied molecules showed direct inhibition of NLRP3 ATPase activity. ${ }^{16-23}$ 


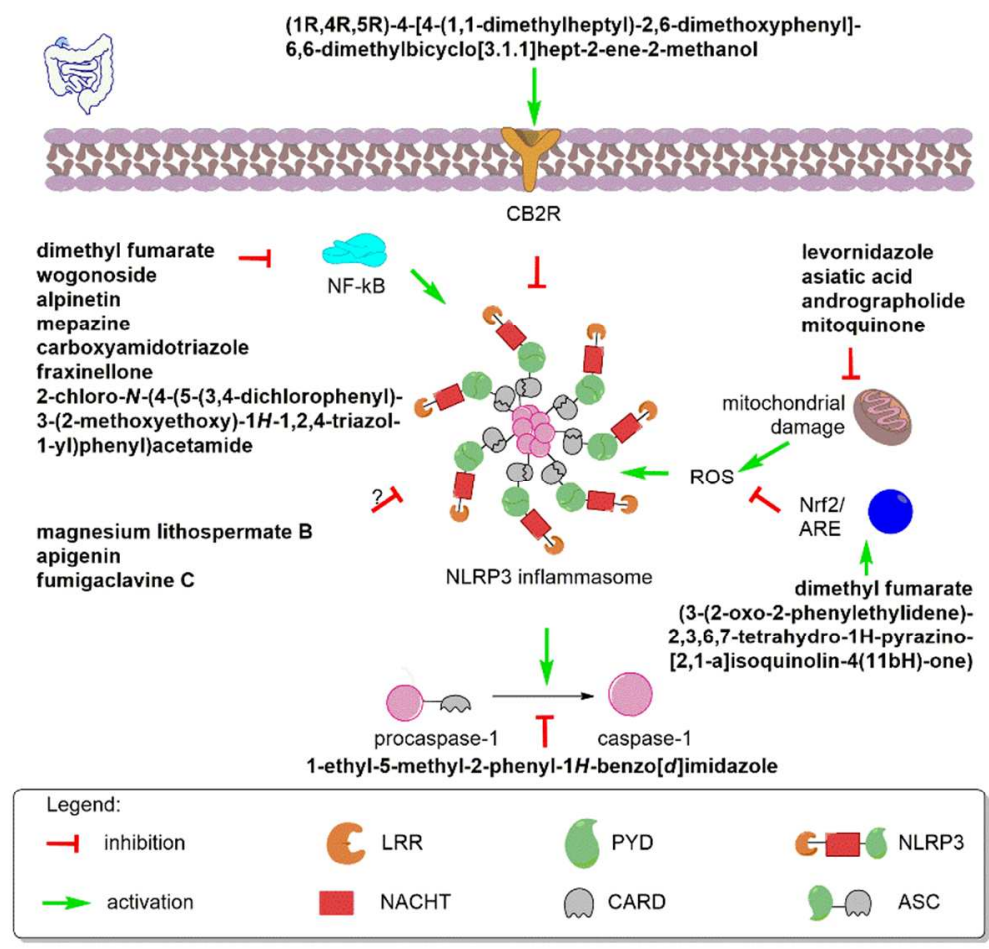

Figure 1. Experimental NLRP3 inflammasome pathway inhibitors studied for the treatment of IBD and their putative mechanism of action (see supporting info for references).

According to these observations, in the present study we explored the use of direct NLRP3 inflammasome inhibitors as potential new tools for the treatment of bowel inflammation.

To design NLRP3 inhibitors suitable for further development we relied on our previous experience with electrophilic warheads. In a proof of concept work we demonstrated that $\alpha, \beta$-unsaturated carbonyl derivatives, behaving as Michael acceptors, can significantly prevent NLRP3-dependent pyroptosis of THP-1 cells. These effects were associated with the inhibition of the NLRP3 ATPase activity. Among the studied compounds those based on the acrylate scaffold showed the most favorable pharmacotoxicological profile, with ethyl 2-((2-chlorophenyl)hydroxyl)methyl)acrylate (INF4E, $\mathbf{1})^{24}$ emerging as a potential lead amenable of further optimization (Figure 2) ${ }^{25}$ Compound $\mathbf{1}$ still suffered from some drawbacks: its reactivity being not perfectly tuned, leading to a certain degree of cytotoxicity in THP-1 cells. As a matter of fact, $\mathbf{1}$ was later shown to bind human serum albumin in fresh human serum by $65 \pm 5 \%$ through the formation of three covalent adducts. ${ }^{26}$ The structure of 1 needed further chemical optimization. In order to modulate the acrylate scaffold toward less toxic compounds, in this work, we followed a simple but straightforward strategy as depicted in Figure 2; in an early phase of the project the chemical modulation of the 2,4-dichlorophenyl-substituted acrylate $\mathbf{2}$, a previously identified close analogue of $\mathbf{1}$ showing good antipyroptotic properties, ${ }^{25}$ was also considered.

Compounds 3 and 4 (Figure 2) were designed to verify whether the presence of a free carboxylic group could lead to active or inactive derivatives. The functionalization (derivatives 5-8, 10) and the removal (derivatives 11-14) of the benzylic hydroxyl group was performed to investigate the role played by this moiety in the reactivity and the cytotoxicity of this class of compounds. Final- 
ly, compounds 13 and 14, deprived of the terminal double bond, were synthesized to test their biological activity and allow for mechanistic considerations.

In this work, we describe the selection of $\mathbf{1 1}(\mathrm{INF} 39)^{27}$ a non-cytotoxic, acrylate-based NLRP3 inhibitor after assessment of the Michael acceptor reactivity, cytotoxicity, in vitro NLRP3 ATPase inhibition, and antipyroptotic properties of a small series of acrylate electrophiles. Furthermore, novel insights into the mechanism of NLRP3-inflammasome inhibition by $\mathbf{1 1}$ are given thanks to its ability to inhibit IL-1 $\beta$ release from macrophages and to affect the activation kinetic profile of NLRP3 measured by bioluminescence resonance energy transfer (BRET). In vitro metabolic stability studies and ex vivo intestinal permeation experiments give a preliminary insight into compound $\mathbf{1 1}$ pharmacokinetic profile. Finally, in vivo pharmacological studies of $\mathbf{1 1}$ in a rat model of colitis show a relevant reduction of gut-associated inflammation.

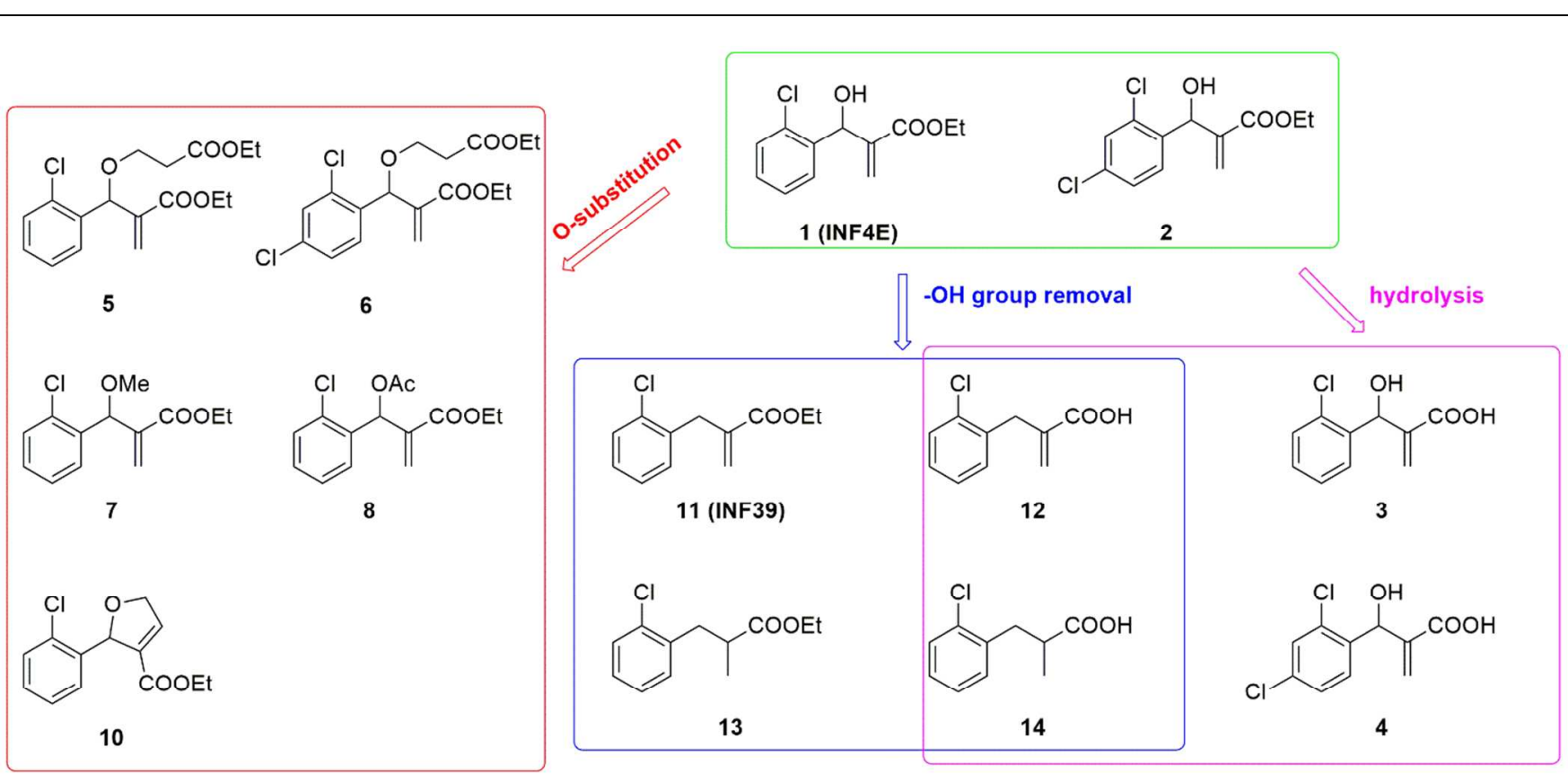

Figure 2. Design of acrylates as NLRP3 inhibitors.

\section{RESULTS AND DISCUSSION}

Chemistry. Derivatives 1 and its dichloro analogue 2, obtained by Morita-Baylis-Hillman (MBH) reaction, ${ }^{25}$ were chosen as the starting materials for the synthesis of the designed compounds (Schemes 1-3). The corresponding acids 3 and 4 were obtained by $\mathrm{NaOH}$-mediated hydrolysis of the ester group in quantitative yields at room temperature (rt) (Scheme 1). O-functionalyzed derivatives $\mathbf{5}$ and 6, which were previously obtained in trace amounts as by-products of the MBH reaction between the corresponding chlorobenzaldehydes and ethylacrylate, ${ }^{25}$ were synthesized from 1 using an oxa-Michael reaction. This reaction was carried out in 
$\mathrm{CH}_{3} \mathrm{CN}$ employing ethylacrylate as the electrophile, 1,5-diazabiciclo[5.4.0]undec-5-ene (DBU), and a stoichiometric amount of 4(dimethylamino)pyridine (DMAP) as the bases affording desired derivatives 5 and $\mathbf{6}$ in about 30\% unoptimized yields (Scheme 1).<smiles>[R]c1ccc(C(O)C(=C)C(=O)OCCOC(C(=C)C(=O)OCC)c2ccc([R])cc2Cl)c(Cl)c1</smiles>

${ }^{a}$ Reagents and conditions: (a) $\mathrm{NaOH} 2.5 \mathrm{M}, 1,4$-dioxane/ $\mathrm{H}_{2} \mathrm{O}$ 1/1, rt, 16 h; (b) ethyl acrylate, DMAP, DBU, $\mathrm{CH}_{3} \mathrm{CN}, \mathrm{rt}, 48 \mathrm{~h}$.

To obtain the methoxy derivative 7, the oxygen atom of 1 was alkylated using an excess of methyl iodide and $\operatorname{Ag}_{2} \mathrm{O}(\mathrm{Scheme} 2)$. After 4 days at rt derivative 7 was obtained in $40 \%$ yield after chromatography. The acetoxymethyl acrylate 8 was efficiently obtained by dropwise addition of acetic anhydride to a mixture of $\mathbf{1}$ containing 0.2 molar equivalents of DMAP. Compound $\mathbf{8}$ was then converted into the O-allyl derivative 9 through displacement of the highly reactive acetoxy group with 2-propenol in dry THF using two equivalents of DABCO as the base. These intermediates were then submitted to a ring-closing metathesis (RCM) reaction using the $2^{\text {nd }}$ generation Hoveyda-Grubbs catalyst 1,3-bis-(2,4,6-trimethylphenyl)-2-imidazolidinylidene)dichloro(oisopropoxyphenylmethylene)ruthenium to yield $\mathbf{1 0}$ in fair yields. Unfortunately, after isolation, $\mathbf{1 0}$ decomposed either in solution or on overnight standing giving rise to a complex mixture. From this mixture only about $34 \%$ of $\mathbf{1 0}$ could be recovered by silicagel column chromatography after $20 \mathrm{~h}$ of storage at $-18^{\circ} \mathrm{C}$. Consequently, we were able to chemically characterize $\mathbf{1 0}$ by NMR and MS, however, due to its chemical instability, in the continuation of this work it was possible to use derivative $\mathbf{1 0}$ only for the determination of its reactivity toward thiol groups. $\mathrm{NaBH}_{4}$-mediated reduction of $\mathbf{8}$, conducted in a mixture of $\mathrm{THF} / \mathrm{H}_{2} \mathrm{O}(1 / 1)$ in the presence of DABCO, afforded $\mathbf{1 1}$ in 84\% yield. This compound was then hydrolyzed using the above reported method to furnish $\mathbf{1 2}$ (Scheme 2). Finally, Pd-catalyzed hydrogenation of $\mathbf{1}$ and subsequent hydrolysis allowed us to obtain probe derivatives $\mathbf{1 3}$ and $\mathbf{1 4}$ in high yields (Scheme 3).

\section{Scheme 2. Synthesis of compounds 7-12}




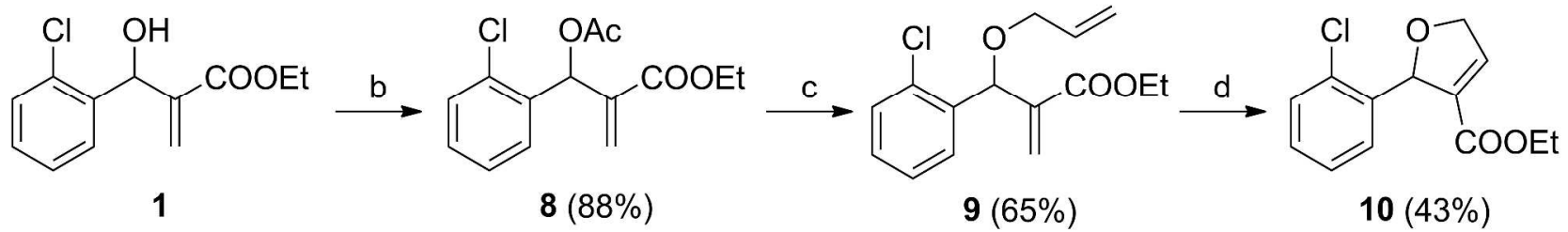<smiles>C=C(C(=O)OCC)C(O[Al]C(C)C)c1ccccc1Cl</smiles>

$7(40 \%)$<smiles>C=C(Cc1ccccc1Cl)C(=O)OCC(=O)OCc1ccccc1</smiles>

${ }^{a}$ Reagents and conditions: (a) $\mathrm{Ag}_{2} \mathrm{O}, \mathrm{CH}_{3} \mathrm{I}, \mathrm{CH}_{2} \mathrm{Cl}_{2}, \mathrm{rt}, 4$ d; (b) $\mathrm{Ac}_{2} \mathrm{O}$, DMAP, $\mathrm{CH}_{2} \mathrm{Cl}_{2}$, rt, 40 min; (c) 2-propenol, DABCO, dry THF, rt,

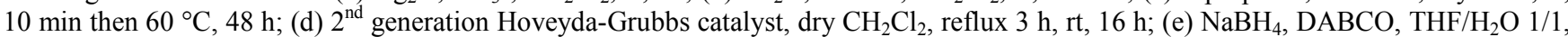
rt, 30 min; (f) $\mathrm{NaOH} 2.5 \mathrm{M}, 1,4$-dioxane $/ \mathrm{H}_{2} \mathrm{O}$ 1/1, rt, 16 h.

Scheme 3. Synthesis of compounds 13-14<smiles>C=C(C(=O)OCC)C(O)c1ccccc1Cl</smiles><smiles>CC(Cc1ccccc1Cl)C(=O)O</smiles>

${ }^{a}$ Reagents and conditions: (a) $\mathrm{H}_{2}, \mathrm{Pd} / \mathrm{C}\left(10 \%\right.$ ), abs EtOH, rt, 30 min; (b) NaOH $2.5 \mathrm{M}, 1$,4-dioxane/ $\mathrm{H}_{2} \mathrm{O}$ 1/1, rt, $16 \mathrm{~h}$.

Reactivity as Michael acceptor. The ability of the reference compound $\mathbf{1}$ and of the synthesized compounds $\mathbf{2 - 8 , 1 0 - 1 4}$ to react with thiol groups was determined using the kinetic cysteamine chemoassay previously described ${ }^{25,26}$ Compounds were mixed with an equimolar amount of cysteamine (CAM) in $\mathrm{pH} 7.4$ phosphate-buffered solution at $37{ }^{\circ} \mathrm{C}$ using $\mathrm{CH}_{3} \mathrm{CN}$ as the cosolvent. The progress of the reaction was monitored adding 5,5'-dithio-bis(2-nitrobenzoic acid) (DTNB reagent) at different time points over a period of $90 \mathrm{~min}$, obtained results are collected in Table 1. The reference compound $\mathbf{1}$ showed a $k_{2}$ value of $0.824 \pm 0.017 \mathrm{M}^{-1} \mathrm{~s}^{-1}$, surprisingly its dichloro-analogue 2 proved more reactive with a $k_{2}$ value of $1.340 \pm 0.220 \mathrm{M}^{-1} \mathrm{~s}^{-1}$. As expected, the corresponding acrylic acids 3 and $\mathbf{4}$ did not show any reactivity in the test conditions. The series of compounds bearing a substituted oxygen atom in benzylic position maintained the ability to react with thiols. Derivatives 5 and 6 showed $k_{2}$ values $\left(0.734 \pm 0.047 \mathrm{M}^{-1} \mathrm{~s}^{-1} ; 0.292 \pm\right.$ $0.014 \mathrm{M}^{-1} \mathrm{~s}^{-1}$, respectively) lower than that shown by parent 1 . The methoxy-substituted compounds 7 showed an increased electro- 
philic ability $\left(k_{2}=1.60 \pm 0.056 \mathrm{M}^{-1} \mathrm{~s}^{-1}\right)$ which was maximized when the acetoxy group was introduced in benzylic position as in compound $8\left(k_{2}=56.2 \pm 5.4 \mathrm{M}^{-1} \mathrm{~s}^{-1}\right)$. When the oxygen atom was enclosed in a dihydrofuran ring $(\mathbf{1 0})$ a compound with about tenfold the reactivity of parent 1 was obtained. Finally, removal of the $\mathrm{OH}$ group afforded a compound (11) endowed with no apparent Michael reactivity in our assay conditions. Moreover, when the assay was repeated using glutathione as a model of biological relevant thiol, no reactivity of $\mathbf{1 1}$ was detected both at $\mathrm{pH} 7.4$ and $\mathrm{pH} 9.0$ (data not shown). To ascertain the electrophilicity of the acrylic ester 11, its ability to react with thiols under different test conditions was then checked. Compound $\mathbf{1 1}$ was reacted with an excess of CAM in pH 7.4 phosphate-buffered solution at $37{ }^{\circ} \mathrm{C}$ using $\mathrm{CH}_{3} \mathrm{CN}$ as the cosolvent. The decrease in $\mathbf{1 1}$ concentration was monitored by UHPLC for $4 \mathrm{~h}$. In these conditions, the concentration of $\mathbf{1 1}$ decreased to $89.4 \pm 1.5 \%, 83.3 \pm 2.1 \%$, and $77.5 \pm$ $3.2 \%$ after $30 \mathrm{~min}, 60 \mathrm{~min}$, and $4 \mathrm{~h}$, respectively, thereby indicating a slow in vitro reactivity with thiol groups (Figure S2).

While 11 proved to be a weak electrophile (a necessary requirement for the development of safe covalent drugs), other known NLRP3 inflammasome inhibitors such as BAY 11-7082 (BAY), ${ }^{28} 3,4$-methylenedioxy- $\beta$-nitrostyrene (MNS) ${ }^{29}$ and dimethylfumarate (DiMF) showed a markedly higher reactivity as nucleophiles than 11. In particular MNS showed a $k_{2}=2.50 \pm 0.12 \mathrm{M}^{-}$ ${ }^{1} \mathrm{~s}^{-1}$ while DiMF a $k_{2}=39.01 \pm 0.57 \mathrm{M}^{-1} \mathrm{~s}^{-1}$. Noteworthy, the reactivity of BAY with CAM was too fast to determine a reliable $k_{2}$ value.

To further characterize the reactivity of $\mathbf{1 1}$ toward biological nucleophiles in quasi-physiological conditions we tested its reactivity toward human serum albumin (HSA) in fresh human serum. This method was recently reported as a valid test for monitoring the reactivity of Michael acceptors with unspecific endogenous targets, relying on HSA as a multifunctional probe that contains a set of self-activated nucleophiles with diverse chemistries and accessibilities. ${ }^{30}$ Unlike compound 1, compound $\mathbf{1 1}$ (which proved stable in human serum; Figure S3) showed no reactivity toward HSA. In fact, a 3-hour incubation of compound $\mathbf{1}$ into human serum resulted in a modification of the mass spectrum of HSA due to covalent binding, while the corresponding spectra from serum incubated with compound 11 and from a control sample were superimposable. In detail, Figure 3 reports the mass spectra of HSA obtained from serum (Figure 3A), serum treated with compound 11 (Figure 3B) and serum treated with compound 1 (Figure 3C). As reported in the spectra in Figure $3 \mathrm{~A}-\mathrm{B}$, in the $1400-1500 \mathrm{~m} / \mathrm{z}$ region there are 3 main signals corresponding to HSA multiply charged ions $\left[\mathrm{HSA}+\mathrm{zH}^{+}\right]^{2+}$ with charge $(\mathrm{z})$ values between $45+$ and $47+$, accompanied by the corresponding ions of cysteinylated HSA (HSA-SCys) and glycated HSA (HSA-N-Glc). The additional signals in figure $3 \mathrm{C}$ have $\mathrm{m} / \mathrm{z}$ values corresponding to $+240 \mathrm{Da}$ increments of the molecular weight of HSA, which is the expected value for compound $\mathbf{1}$ covalent adducts. Therefore, compound $\mathbf{1 1}$ can be regarded as a weak "safe" electrophile suggesting the possible absence of unspecific reactivity toward biological nucleophiles and a reduced possibility to trigger idiosyncratic hypersensitivity reactions. 
$1414.8(47+)$
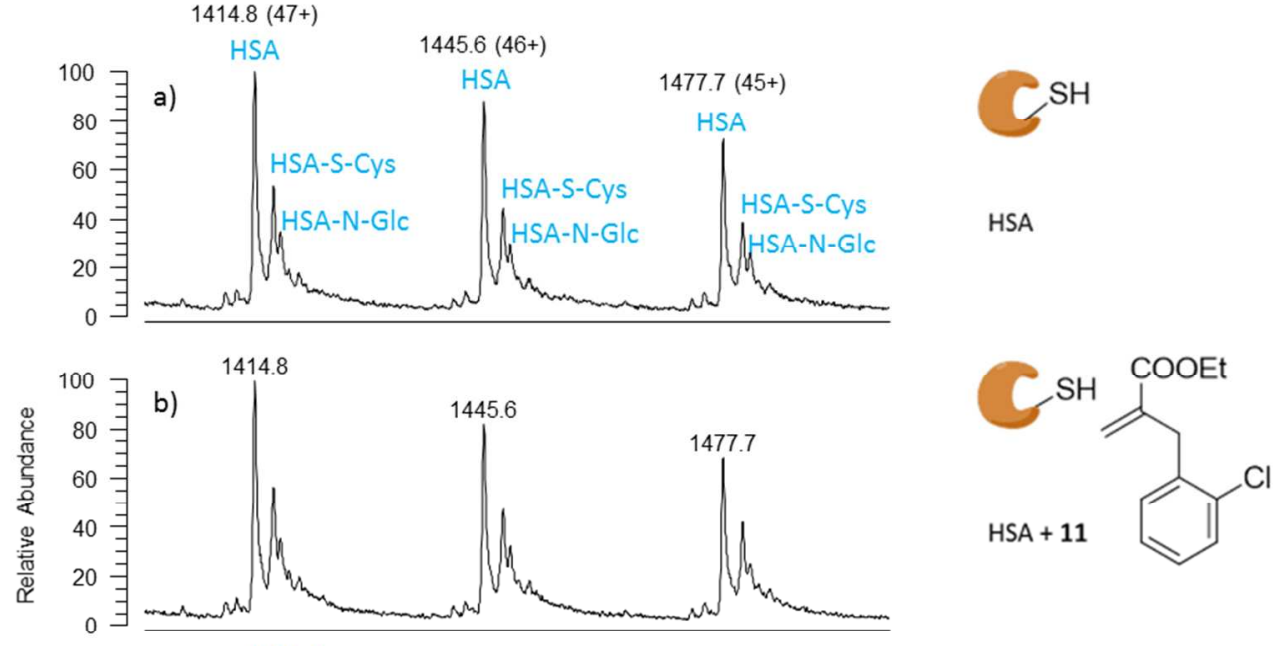

Assessment of cytotoxicity in THP-1 cells. To select candidates for further in vitro and in vivo studies, cytotoxic activity was evaluated. Human THP-1 cells were exposed to increasing concentrations of the synthesized compounds $(0.1-100 \mu \mathrm{M}, 72 \mathrm{~h})$, then cell viability was evaluated by MTT assay. ${ }^{26}$ As shown in Table 1 , a $\mathrm{TC}_{50}$ (the concentration able to decrease cell viability by $50 \%$ ) value $\leq 100 \mu \mathrm{M}$ was determined for the parent compounds $\mathbf{1 , 2}$ and the highly reactive compound $\mathbf{8}$. A $\mathrm{TC}_{50}$ value $>100 \mu \mathrm{M}$ was instead observed for the other compounds, thus indicating that a decreased cytotoxicity was achieved by introducing focused structural modulations. These data demonstrate that the $\alpha$-hydroxy group likely plays a dual role in $\alpha$-benzyl acrylates electrophiles regulating both reactivity, due to its effect on the carboxylate moiety, ${ }^{31}$ and toxicity. Owing to the differences in the $\mathrm{TC}_{50}$ values among 1 vs compounds 5 and 7 (less and more reactive than 1, respectively), it could be suggested that the cytotoxicity of this class of compounds does not entirely depend on their reactivity toward thiols.

The cytotoxicity of other electrophilic NLRP3 pathway inhibitors, namely MNS, BAY, and DiMF was determined in THP-1 cells using the same assay. As shown in Table 1, compared to $\mathbf{1 1}\left(\mathrm{TC}_{50}>100 \mu \mathrm{M}\right)$ both MNS and BAY resulted markedly more cytotoxic $\left(\mathrm{TC}_{50} 3.2 \pm 0.8\right.$, and $1.5 \pm 0.3 \mu \mathrm{M}$, respectively) while DiMF showed a slightly higher toxicity $\left(\mathrm{TC}_{50} 95.5 \pm 1.2 \mu \mathrm{M}\right)$. Re- 
sults obtained with reference NLRP3 pathway inhibitors showed that, also in this case, cytotoxicity is related not only to the electrophilic reactivity but also to other structural parameters as evidenced by comparing reactivity and cytotoxicity for MNS vs DiMF (Table 1).

Inhibition of NLRP3 ATPase activity. The ability of non-toxic compounds to inhibit the NLRP3 ATPase activity was tested on purified human recombinant protein. Human recombinant NLRP3 was incubated at $37^{\circ} \mathrm{C}$ in the presence of two different concentrations $(100 \mu \mathrm{M}, 50 \mu \mathrm{M})$ of tested compounds for $15 \mathrm{~min}$. ATP $(250 \mu \mathrm{M})$ was then added and the mixture incubated at $37^{\circ} \mathrm{C}$ for further $40 \mathrm{~min}$. The amount of ATP converted to ADP was determined by luminescence using the ADP-Glo assay. ${ }^{26}$ The obtained results, expressed as percentage of enzyme inhibition with respect to vehicle treated enzyme, are reported in Table 1. All the tested acrylates inhibited NLRP3 ATPase activity at $100 \mu \mathrm{M}$; as expected, propanoic acid derivatives $\mathbf{1 3}$ and 14, showed a negligible activity suggesting that the presence of electrophilic acrylate moiety is essential for NLRP3 ATPase inhibition for this series of compounds. The inhibition of NLRP3 ATPase appeared to be concentration-dependent. Derivatives 1-3, 5, 7, 11, and 12 showed the most interesting activities at $50 \mu \mathrm{M}$, with an inhibition spanning the $19-32 \%$ range.

Collectively these data indicate that the acrylate derivatives with reduced reactivity inhibit the NLRP3 ATPase activity which is necessary for the NLRP3 inflammasome assembly and activation, ${ }^{32}$ consequently they can be effectively used as NLRP3 blockers.

Antipyroptotic activity. To assess the ability of the synthesized compounds to affect a NLRP3-dependent cellular response, their effect on the ATP-triggered pyroptosis of THP-1 cells was evaluated. ${ }^{25}$ Pyroptosis was significantly decreased by compounds 1-7, 11, and 12 (all at $10 \mu \mathrm{M}$; Table 1). No effect was exerted by derivatives 13 and 14, lacking the acrylate substructure. Compounds were classified into two subclasses: highly active (70-80\% pyroptosis inhibition), such as $\alpha$-hydroxymethyl acrylates $\mathbf{1}$ and 2; and moderately active (30-60\% inhibition), including derivatives 3-7, 11, and 12. Of note, an antipyroptotic activity was determined for the carboxylic acids $\mathbf{3}, \mathbf{4}$, and $\mathbf{1 2}$, suggesting that these compounds, being the putative cellular metabolites of parent ester derivatives 1, 2, and $\mathbf{1 1}$ respectively, can maintain the in cell activity; this is not surprising taking into account their ability to act as direct NLRP3 ATPase inhibitors. Compared with the monochloro derivatives $\mathbf{1 , 3}$, and $\mathbf{5}$, the more lipophilic dichloro-substituted derivatives 2, 4, and $\mathbf{6}$ showed similar or lower NLRP3 ATPase inhibition and antipyroptotic properties, therefore, the development of dichloro-substituted compounds was discontinued.

Analysis of the overall data, together with synthetic considerations, prompted us to choose $\mathbf{1 1}$ for further studies. $\mathbf{1 1}$ is a nontoxic ethyl acrylate derivative showing an acceptable degree of reactivity toward thiol groups. Compound $\mathbf{1 1}$ inhibits NLRP3 ATPase in a concentration-dependent manner and prevents pyroptosis of THP-1 cells; moreover, it can be easily synthesized in high yield (74\%) from 1 allowing the possibility to produce multigram amounts of compound for in vivo studies. 
Table 1. Reactivity with cysteamine, cytotoxicity, NLRP3 ATPase inhibition, and antipyroptotic activity of synthesized compounds 1-8, 10-14, and reference inhibitors MNS, BAY, DiMF.

\begin{tabular}{|c|c|c|c|c|c|c|}
\hline \multirow[t]{2}{*}{ Compd } & \multirow[t]{2}{*}{$\begin{array}{l}\text { Reactivity } \\
k_{2}\left(\mathrm{M}^{-1} \mathrm{~s}^{-1}\right)^{a}\end{array}$} & \multirow[t]{2}{*}{$\begin{array}{c}\text { Cytotoxicity } \mathrm{TC}_{50}(\mu \mathrm{M})^{b} \\
{[\% \text { viability }]}\end{array}$} & \multicolumn{2}{|c|}{$\begin{array}{c}\text { NLRP3 ATPase inhibition } \\
(\%)^{c}\end{array}$} & \multirow[t]{2}{*}{${\text { Pyroptosis decrease }(\%)^{d}}^{d}$} & \multirow[t]{2}{*}{$\operatorname{cLog} \mathrm{P}^{e}$} \\
\hline & & & $100 \mu \mathrm{M}$ & $50 \mu \mathrm{M}$ & & \\
\hline 1 & $0.824 \pm 0.017$ & $65.0 \pm 5.0$ & $72 \pm 14$ & $32 \pm 11$ & $80.9 \pm 5.7^{f}$ & 2.59 \\
\hline 2 & $1.340 \pm 0.220$ & $68.3 \pm 5.1$ & $35 \pm 8$ & $19 \pm 5$ & $74.4 \pm 2.1$ & 3.30 \\
\hline 3 & Not Reactive & $>100[80.7 \pm 3.2]$ & $69 \pm 12$ & $21 \pm 7$ & $45.0 \pm 6.9^{g}$ & $1.53^{h}$ \\
\hline 4 & Not Reactive & $>100[88.1 \pm 4.2]$ & $43 \pm 1$ & $11 \pm 6$ & $40.2 \pm 6.6$ & $2.24^{h}$ \\
\hline 5 & $0.734 \pm 0.047$ & $>100[95.7 \pm 6.2]$ & $56 \pm 2$ & $27 \pm 1$ & $58.3 \pm 7.6^{g}$ & 4.06 \\
\hline 6 & $0.292 \pm 0.014$ & $>100[87.7 \pm 7.2]$ & Not soluble & $10 \pm 3$ & $43.9 \pm 7.8^{g}$ & 4.77 \\
\hline 7 & $1.596 \pm 0.056$ & $>100[78.1 \pm 3.7]$ & $60 \pm 11$ & $24 \pm 6$ & $37.2 \pm 6.7$ & 3.44 \\
\hline 8 & $56.2 \pm 5.4$ & $33.3 \pm 7.7$ & Not Tested & Not Tested & Not Tested & 3.42 \\
\hline 10 & $8.182 \pm 0.043$ & Not Tested & Not Tested & Not Tested & Not Tested & 3.40 \\
\hline 11 & Not Reactive. & $>100[96.6 \pm 2.4]$ & $52 \pm 10$ & $29 \pm 8$ & $33.6 \pm 7.1$ & 3.92 \\
\hline 12 & Not Reactive & $>100[102.1 \pm 4.5]$ & $44 \pm 9$ & $22 \pm 4$ & $35.8 \pm 2.0$ & $2.94^{h}$ \\
\hline 13 & Not Reactive & $>100[86.1 \pm 4.2]$ & $12 \pm 2$ & inactive & $3.8 \pm 2.1$ & 3.83 \\
\hline 14 & Not Reactive & $>100[98.7 \pm 3.2]$ & $15 \pm 6$ & inactive & $5.2 \pm 3.3$ & $2.92^{h}$ \\
\hline MNS & $2.50 \pm 0.12$ & $3.2 \pm 0.8$ & Not Tested & Not Tested & Not Tested & 2.18 \\
\hline BAY & Not Applicaple ${ }^{\mathrm{i}}$ & $1.5 \pm 0.3$ & Not Tested & Not Tested & Not Tested & 0.94 \\
\hline DiMF & $39.01 \pm 0.57$ & $95.5 \pm 1.2$ & inactive & inactive & $65.2 \pm 3.1$ & 0.78 \\
\hline
\end{tabular}

${ }^{a}$ Compounds $(250 \mu \mathrm{M})$ were reacted with equimolar amount of CAM in pH $7.4 \mathrm{PBS}$ containing $12.5 \% \mathrm{CH}_{3} \mathrm{CN}$ at $37{ }^{\circ} \mathrm{C}$. The decrease in free CAM was monitored using DTNB reagent at different time points during $90 \mathrm{~min}$. Second-order rate constants, calculated according to the equation $1 / c_{C A M}=1 / c_{C A M}^{0}+k t$, were determined from 3-10 data points per rate plot. ${ }^{b} \mathrm{THP}-1$ cells were exposed to increasing concentrations $(0.1-100 \mu \mathrm{M})$ of each compounds and cell viability was measured at $72 \mathrm{~h}$ by MTT assay. $\mathrm{TC}_{50}$ represents the concentration of compound which decreases cell viability by $50 \%$. The percentage of viable cells at $72 \mathrm{~h}$ exposed to compound (100 $\mu \mathrm{M})$ is in brackets. DMSO used as the cosolvent had no effect. ${ }^{c}$ Compounds were incubated with isolated NLRP3 for 20 min, then ATP $250 \mu \mathrm{M}$ was added and its conversion to ADP was measured by the ADP-Glo assay. Data are expressed as percentage of inhibition vs vehicle alone. ${ }^{d}$ PMAdifferentiated and LPS-primed THP-1 cells were pre-treated with either vehicle alone or each compound (10 $\mu \mathrm{M} ; 1 \mathrm{~h})$. Pyroptosis was triggered with ATP $(5 \mathrm{mM})$ and LDH activity was measured in the collected supernatant $1 \mathrm{~h}$ after ATP exposure by a colorimetric assay. Data are expressed as percent of pyroptosis decrease vs vehicle alone. $k_{2}$ values and biological data are expressed as mean \pm SEM of at least three separate experiments. DMSO used as the cosolvent had no effect. ${ }^{e}$ Calculated with ChemBioDraw Ultra 12.0, CambridgeSoft. ${ }^{f}$ Ref. 26. ${ }^{g}$ Ref $25 . ;{ }^{h} c$ LogPN. ${ }^{i}$ Too high to be measured.

Compound 11 inhibits IL-1ß release. We next compared the ability of 11 with other inhibitors of NLRP3 inflammasome signaling pathway to block IL-1 $\beta$ release from macrophages after NLRP3 activation. LPS-primed mouse bone marrow-derived macrophages (BMDM) were exposed for $1 \mathrm{~h}$ to different concentrations of $\mathbf{1 1}$ and thereafter NLRP3 was activated with the classical activating stimuli extracellular ATP or nigericin. 11 was able to significantly inhibit ATP- and nigericin-induced IL-1 $\beta$ release at 10 $\mu \mathrm{M}$ (Figure 4A,B). The inhibition of IL-1 $\beta$ release by 11 was similar or even greater than that observed by DiMF but less than that of BAY (Figure 4A,B). Furthermore, 11 reduced caspase-1 activation and pyroptosis (measured as extracellular LDH) in these macrophages (Figure 4C-F). Compared to DiMF and BAY, compound 11 was more effective in blocking pyroptosis (Figure 4C,D). 
We next assessed the ability of $\mathbf{1 1}$ to block LPS induced pro-inflammatory gene expression. When the macrophages were exposed to $111 \mathrm{~h}$ before LPS priming, the expression of Tnfa, Il6 and Illb genes was significantly decreased (Figure 4G), suggesting that $\mathbf{1 1}$ could not only block NLRP3 activation, but also the NF-אB pathway. Next, as compound $\mathbf{1 1}$ could potentially react with Cys-SH residues in the active site of cysteine protease caspase-1, we next assessed the ability of $\mathbf{1 1}$ to inhibit caspase-1 activity. Recombinant human caspase-1 activity was unaffected by different concentrations of $\mathbf{1 1}$ (Figure 4H), suggesting that $\mathbf{1 1}$ did not directly target caspase-1 activity.

This result can be considered a further improvement in terms of selectivity of $\mathbf{1 1}$ compared to 1, previously found to irreversibly inhibit caspase-1. ${ }^{25}$ This behavior confirms that highly reactive acrylates (i.e. 1) can interact unspecifically with biological nucleophiles (such as HSA or caspase-1), while better selectivity is achieved by reducing the electrophilicity as with compound $\mathbf{1 1}$, thus compensating the loss of potency that is usually obtained with weak electrophiles.

Dexamethasone (DEX), a standard steroidal drug used in the treatment of IBD, was also studied. Interestingly, DEX exerted significant anti-pyroptotic effects at 100 and $250 \mathrm{nM}$ in mouse BMDM without any effects on IL-1 $\beta$ release.

A

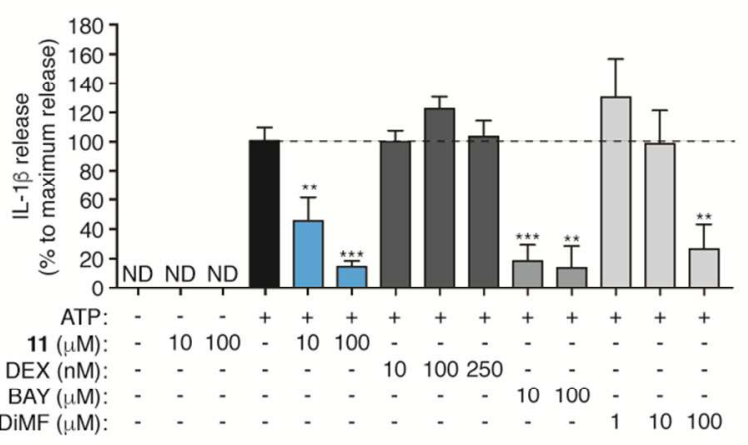

C
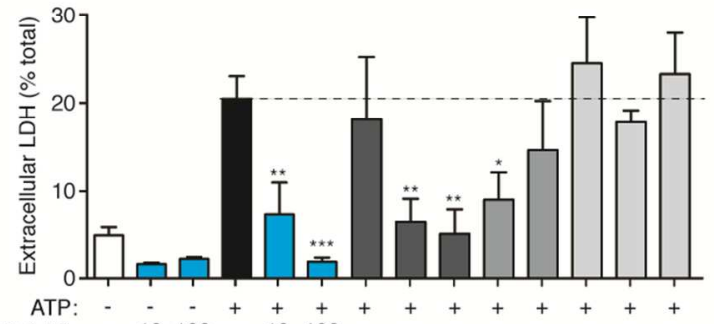

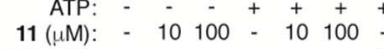
DEX (nM): BAY $(\mu \mathrm{M})$ :

E $\operatorname{DiMF}(\mu \mathrm{M})$

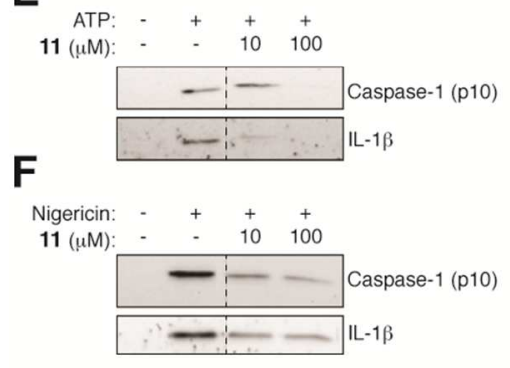

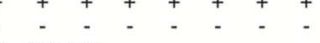

G

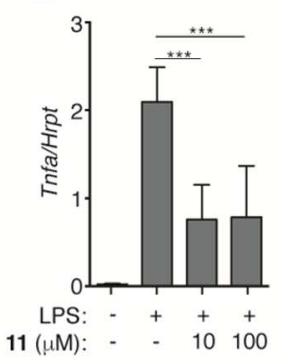

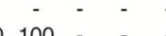

B

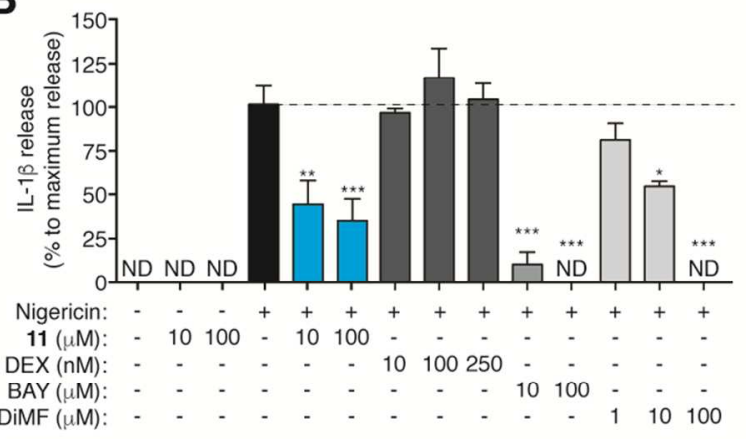

D

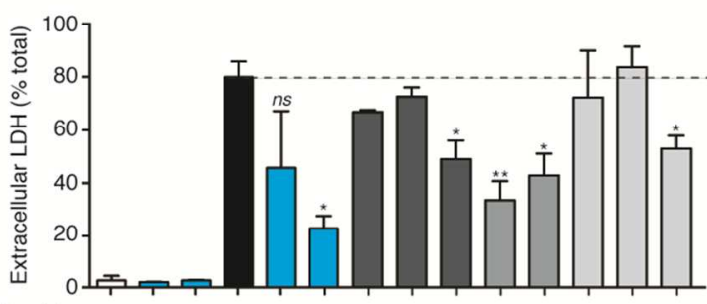

Nigericin: - - -++++++++++

$11(\mu \mathrm{M}):-10100-10100-\quad-\quad-\quad-\quad-\quad-$

$\operatorname{DEX}(\mathrm{nM}): \quad-\quad-\quad-\quad-\quad-\quad-10100250 \quad-\quad-\quad-\quad-\quad$

BAY $(\mu \mathrm{M})$ : DiMF $(\mu \mathrm{M})$ :

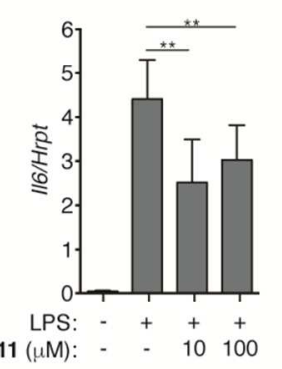

H

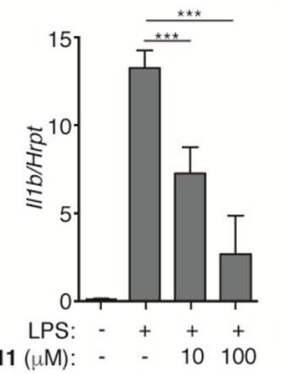

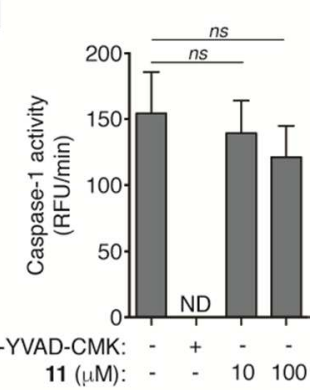


Figure 4. Effect of 11 on IL-1 $\beta$ release and caspase-1 activation in macrophages. (A, B) ELISA for IL-1 $\beta$ release from LPS-primed BMDM $(1 \mu \mathrm{g} / \mathrm{mL}, 3 \mathrm{~h})$, then incubated with 11, DEX, BAY, DiMF or vehicle $(1 \mathrm{~h})$ and stimulated with ATP $(5 \mathrm{mM}, 30$ min, panel A) or nigericin (10 $\mu \mathrm{M}, 30$ min, panel B). (C, D) Percentage of extracellular LDH vs total intracellular LDH from macrophages treated as in A or B. (E, F) Western blot of mature caspase-1 (p10 fragment) and mature IL-1 $\beta$ (p17 fragment) in macrophage supernatants treated as in A or B. (G) Relative gene expression ( $2^{-\Delta C t}$ ) for Tnfa, $I l 6$ and $I l l b$ determined by quantitative RT-PCR from BMDMs incubated with $\mathbf{1 1}$ at indicated concentrations (30 $\mathrm{min})$ and then treated or not with LPS $(1 \mathrm{ng} / \mathrm{mL}, 4 \mathrm{~h})$. (H) Recombinant human caspase-1 (10 U) activity incubated with Ac-YVAD-CMK $(100 \mu \mathrm{M})$ or the indicated concentrations of 11. Western blots are a composite from separated lanes from the same blot/image exposed the same time (as denoted by a dotted line). Each column in A-D, G, H represents the mean \pm SEM. ( $n=3$ independent experiments). ${ }^{*} \mathrm{P}<0.05 ;{ }^{*} \mathrm{P}<0.01 ;{ }^{* * *} \mathrm{P}<0.001 ; n s$ : not significant $(\mathrm{P}>0.05)$; One-way ANOVA with Bonferroni’s post-test.

Mechanism of NLRP3 inhibition by 11. To further investigate the mechanism of action of 11, we used HEK293 cells expressing NLRP3 fused to Luciferase and the yellow fluorescence protein (YFP) (Figure S4A) to record BRET signal that allowed us to follow NLRP3 conformational changes during its activation. ${ }^{33,34}$ The recombinant receptor NLRP3 was functional as it was able to recover nigericin-induced IL-1 $\beta$ release when expressed in NLRP3-deficient macrophages (Figure S4B). After $24 \mathrm{~h}$ incubation, 11 was able to reduce the steady state (or basal) BRET signal of NLRP3 (Figure 5A) without affecting viability of cells (Figure S4C), meaning that 11 could interfere with the basal NLRP3 conformation. After nigericin treatment, BRET signal for NLRP3 decreases and then recovers with time (Figure 5B). ${ }^{34}$ These changes result from the conformational changes of NLRP3 protein during activation as a consequence of the intracellular $\mathrm{K}^{+}$decrease induced by nigericin, since they could be avoided by applying nigericin in a buffer with $140 \mathrm{mM}$ of $\mathrm{K}^{+}$(Figure 5B). 11 did not affect the initial drop in BRET signal, but was able to impair the recovery of BRET (Figure 5B). As a control, high $\mathrm{K}^{+}$buffer or 11-containing vehicle buffer did not change NLRP3 BRET signal over time (Figure S4D). When measuring the slope of the three phases for the BRET variation after nigericin treatment (Figure S4E), we found that $\mathbf{1 1}$ was able to significantly affect the second phase of conformational changes upon stimulation (Figure 5C). Taken together, 11 did not block the initial conformational changes suffered by NLRP3 upon sensing the decrease of intracellular $\mathrm{K}^{+}$, however it affected a second step of NLRP3 conformational change that could be related with the ATPase activity of the receptor and being independent on the decrease of intracellular $\mathrm{K}^{+}$. To confirm the independency of NLRP3 ATPase activity from $\mathrm{K}^{+}$the previously described NLRP3 ATPase assay was performed using high $\mathrm{K}^{+}$concentration $(140 \mathrm{mM})$ in the test buffer. In these conditions the ATPase activity of NLRP3 protein was unaffected (data not shown).

Compounds 11 and its close non-electrophilic analogue $\mathbf{1 3}$ (used as a probe derivative) were further tested to verify the irreversible inhibition of the NLRP3 ATPase activity by $\mathbf{1 1}$. The His-FLAG-tags NLRP3 protein was immobilized on a 96-well plate using 
Flag Ab. NLRP3 ATPase activity was assayed introducing a washing step after preincubation with tested compounds, before ATP addition. In these conditions 11 behaved as a covalent inhibitor ( $45 \pm 1 \%$ inhibition without washing; $40 \pm 4 \%$ with washing), while its close analogue 13 showed a fully restored ATPase activity after the washing step (10 $\pm 1 \%$ inhibition without washing; no detectable inhibition with washing). According to the obtained results, despite the limited potency on isolated enzyme of compound 11, its irreversible NLRP3 inhibition can offer pharmacological advantages such as a prolonged time of action typical of targeted covalent inhibitors. ${ }^{35}$

A

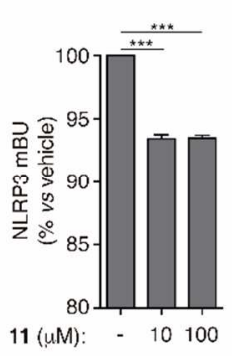

C

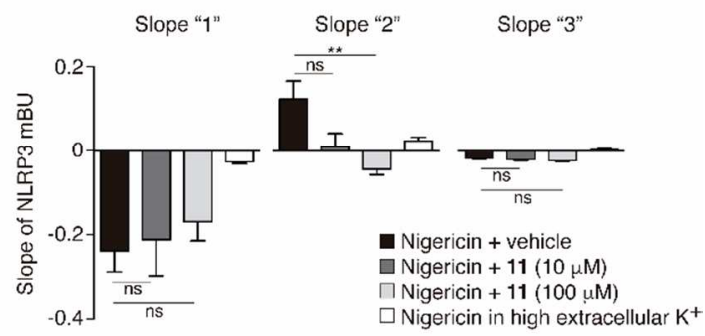

B

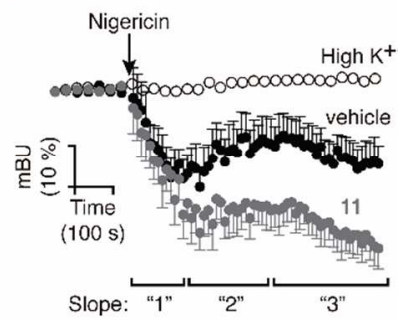

$\square$ Nigericin $+11(100 u M)$

$\square$ Nigericin in high extracellular $\mathrm{K}^{+}$

Figure 5. Compound 11 affects $\mathrm{K}^{+}$-independent conformational changes of NLRP3 during activation. (A) Basal BRET signal from HEK293 cells expressing recombinant YFP-NLRP3-Luc receptor and incubated for $24 \mathrm{~h}$ with vehicle or the indicated concentrations of $\mathbf{1 1}$ ( $n=10$ independent experiments). (B) Kinetics of the NLRP3 BRET signal in response to $10 \mu \mathrm{M}$ nigericin in vehicle buffer (black circles), high $\mathrm{K}^{+}$buffer (white circles), or with $11(100 \mu \mathrm{M})$. The arrow indicates when nigericin was added ( $n=5-7$ independent experiments). (C) Slope of the BRET signal in the three phases denoted in B ( $n=5-12$ independent experiments). Each column in A, C or circle in B represent the mean \pm SEM. of the indicated number of experiments. ${ }^{* *} \mathrm{P}<0.01 ;{ }^{* *} \mathrm{P}<0.001 ; n s$ : not significant $(\mathrm{P}>0.05)$; One-way ANOVA with Bonferroni’s post-test.

\section{Characterization of in vitro preliminary ADME profile of compound 11}

Compound 11, able to efficiently inhibit NLRP3-dependent IL-1 $\beta$ release, was selected for in vivo studies in a model of colitis.

However, the measured solubility of 11 in PBS (pH 7.4) was very low $(0.0060 \pm 0.0008 \mathrm{mg} / \mathrm{mL})$, therefore we considered to adopt oral administration using olive oil as the preferred vehicle. Accordingly, we checked the stability of $\mathbf{1 1}$ suspended in olive oil in simulated gastric fluid and simulated intestinal fluid to verify potential early metabolic instability of $\mathbf{1 1}{ }^{36}$ Compound $\mathbf{1 1}$ (1.56 
mg in $100 \mu \mathrm{L}$ olive oil) was incubated at $37^{\circ} \mathrm{C}$ in simulated gastric fluid (SGF) for $2 \mathrm{~h}$, subsequently in simulated intestinal fluid (SIF) for further $2 \mathrm{~h}$. Samples of the fluids were withdrawn at fixed time (0, 30, 60, and $120 \mathrm{~min})$ and analyzed by UHPLC-MS compared to a control sample. ${ }^{37}$ Compound 11 proved stable in both conditions tested with $>99.5 \%$ of $\mathbf{1 1}$ being detected after $2 \mathrm{~h}$ of incubation in both fluids.

The permeability of $\mathbf{1 1}$ through rat small intestine was then evaluated ex vivo with the non-everted intestinal sac method. Despite some shortfalls (e.g. interruption of normal blood flow, lack of a nervous system) this method is widely used to study passive absorption of molecules. ${ }^{38}$ Furthermore, the presence of a mucus layer, the expression of transport proteins and drug metabolism allow this model to provide additional useful data. ${ }^{39}$

A suspension of 11 (12.5 mg in $200 \mu \mathrm{L}$ olive oil) was syringed into intestinal sacs obtained from different segments of rat intestine (duodenum, jejunum, ileum). The filled tissues were incubated at $37^{\circ} \mathrm{C}$ for $2 \mathrm{~h}$. Sample solutions were withdrawn from the serosal side and the amount of analytes was determined by UHPLC-MS. Analysis of the solution withdrawn from the serosal side during the incubation of intestinal sacs filled with $\mathbf{1 1}$ revealed only the presence of the acid derivative 12, while no detectable amount of 11 was found. As reported in Figure 6, the concentration of the acid derivative 12 increased with time in all the intestinal segments, with differences in time onset: ileum $>$ duodenum $>$ jejunum. Cumulative amount of $\mathbf{1 2}$ from sacs filled with $\mathbf{1 1}$ resulted significantly higher in ileum tract than in duodenum and jejunum (Figure 6). Obtained data indicates that $\mathbf{1 1}$ is absorbed and actively metabolized to the corresponding acid $\mathbf{1 2}$ in intestinal cells; the absorption and/or metabolism of $\mathbf{1 1}$ resulted faster and higher in the ileum tract with respect to the other intestinal segments studied.

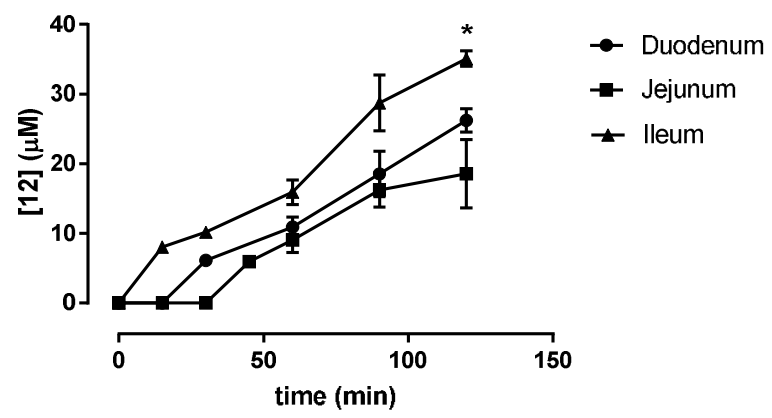

Figure 6. Time-course measurements of permeation of compound $\mathbf{1 1}$ in rat small intestine. Non-everted intestinal sacs were filled with a suspension of $\mathbf{1 1}\left(12.5 \mathrm{mg} / 0.2 \mathrm{~mL}\right.$ olive oil) and incubated in oxygenated Krebs-Ringer buffer at $37^{\circ} \mathrm{C}$ with smooth shaking. Sample solution $(0.5 \mathrm{~mL})$ was withdrawn from the serosal side at fixed time intervals and replaced with fresh buffer. Compound 11 was not detected at the serosal side by UHPLC-MS analysis, while the concentration of its metabolite (12) was quantified. Tests were performed in triplicate on intestinal segments from three different rats. Cumulative amount of 12 at 120 min: * $\mathrm{P}$ $<0.05$ ileum vs duodenum, $\mathrm{P}<0.05$ ileum vs jejunum, t-test. 
Next, we assessed the in vitro stability in rat microsomal fractions ${ }^{40}$ of the metabolite $\mathbf{1 2}$, the sole species identified to pass through gut epithelium in intact intestine. Remarkably, compound $\mathbf{1 2}$ showed a similar in vitro activity and cytotoxicity profile with respect to 11 (Table 1). Since in IBD patients the intestinal barrier is usually damaged and endowed with a higher degree of permeability ${ }^{41}$ we cannot exclude that, in IBD setting, compound $\mathbf{1 1}$ can be absorbed through the loosen cell junctions without undergoing epithelial cleavage. Therefore, the metabolism of $\mathbf{1 1}$ in rat microsomal fractions was also studied. Compounds $\mathbf{1 1}$ and $\mathbf{1 2}$ in DMSO solution (final conc. $100 \mu \mathrm{M}$ with $2 \%$ DMSO) were incubated at $37^{\circ} \mathrm{C}$ for $2 \mathrm{~h}$ in $100 \mathrm{mM} \mathrm{PBS}(\mathrm{pH} 7.4$ ) with rat liver microsomes $(0.5 \mathrm{mg}$ proteins $/ \mathrm{mL})$ in the presence of a NADPH-generating system. The reaction was stopped at different times $(0,15,30,60$, and $120 \mathrm{~min}$ ) and analyzed by UHPLC-MS. In these conditions compound 12 proved stable ( $>99 \%$ of compound detected) giving rise to no detectable metabolites after $2 \mathrm{~h}$ of incubation, while compound $\mathbf{1 1}$ was quantitatively converted to $\mathbf{1 2}$ within a very short time ( $<1 \mathrm{~min}$ ), giving no possibility to measure rate of microsomal clearance of $\mathbf{1 1}$. Of note, when the experiment was repeated with 11 in the absence of NADPH-generating system the same results were obtained, thus indicating that cytochrome-mediated metabolism is not responsible for the generation of $\mathbf{1 2}$.

Collectively, the obtained results suggest that compound $\mathbf{1 1}$ reaches the intestinal epithelium without undergoing chemical modifications. After absorption into epithelial cells it is likely to act locally at the mucosal epithelial level where it is also converted to the non-toxic metabolite 12. This latter compound can diffuse into the blood flow and act systemically without undergoing further hepatic metabolism (Figure 7).

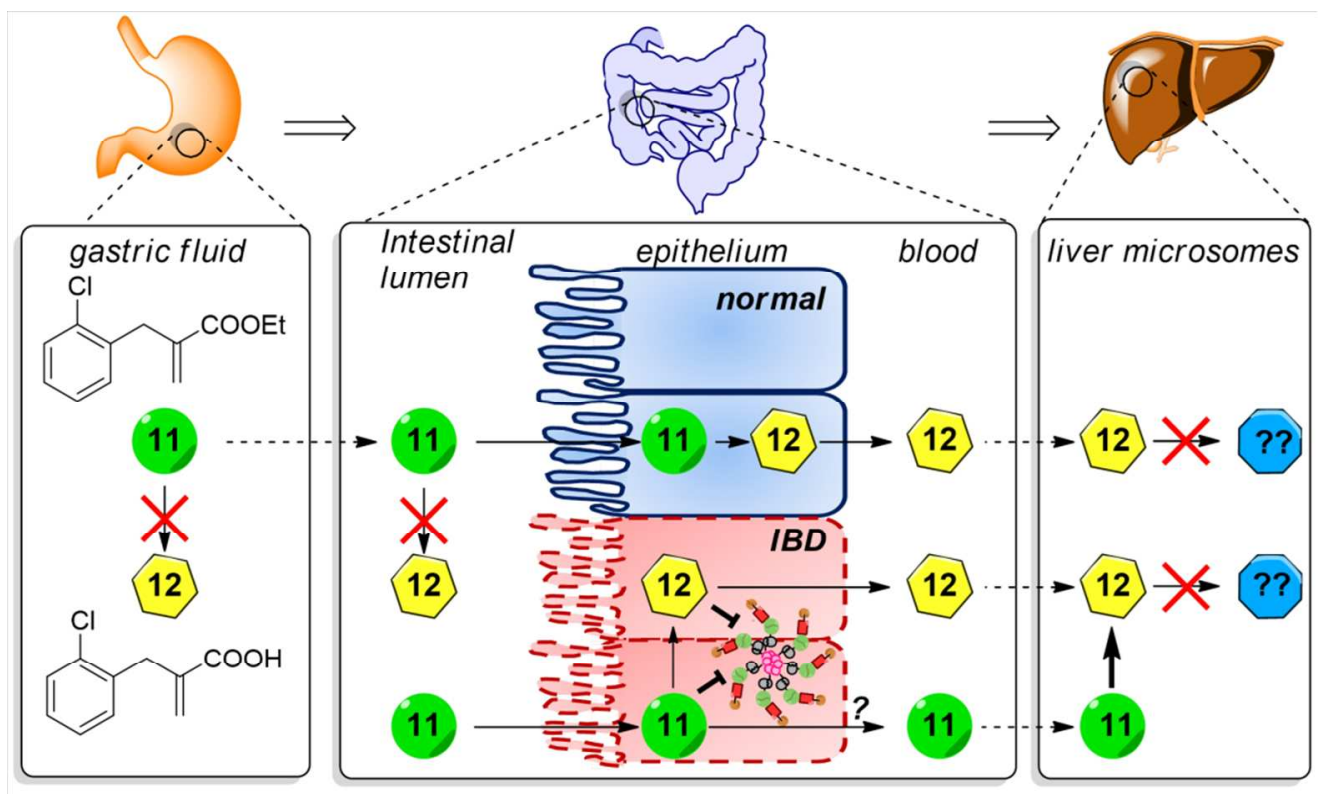

Figure 7. Metabolic fate of compound $\mathbf{1 1}$ and its putative mechanism of action. Following oral administration, $\mathbf{1 1}$ reaches the intestinal epithelium without undergoing metabolic cleavage. After absorption into intestinal epithelial cells, 11 inhibits NLRP3 pathways thanks to both direct NLRP3 inhibition and interference with NF-kB -mediated gene expression. Epithelial intestinal cells 
metabolize compound $\mathbf{1 1}$ to its active acid metabolite 12. This metabolite crosses the basal membrane and diffuses into the blood flow. Compound $\mathbf{1 2}$ is stable to liver metabolism $(2 \mathrm{~h})$. In the presence of a damaged intestinal barrier (as in IBD), compound 11 could potentially diffuse into the blood flow. Once delivered to the liver it is rapidly metabolized to generate the acid $\mathbf{1 2}$.

\section{Oral administration of 11 reduces systemic and colonic inflammation in DNBS-treated rats. To verify the therapeutic po-} tential of using an NLRP3 inhibitor in colonic inflammation, 11 was tested in a rat model of colitis induced by 2,4dinitrobenzenesulfonic acid (DNBS) ${ }^{42}$ in comparison with standard drug dexamethasone (DEX). Briefly, colitis was induced in rats via intrarectal administration of DNBS (15 mg in $0.25 \mathrm{~mL}$ of $50 \%$ ethanol). $11(12.5,25.0,50.0 \mathrm{mg} / \mathrm{kg} / \mathrm{day}$ in $0.2 \mathrm{~mL}$ olive oil) or $\operatorname{DEX}\left(1 \mathrm{mg} / \mathrm{kg}\right.$ day in $0.2 \mathrm{~mL} 1 \%$ methylcellulose $\left.{ }^{43}\right)$ were administered intragastrically for 6 days, starting the same day of colitis induction. Rats treated with different vehicles did not display differences as compared to control group (DNBS-untreated animals) and colitis group (DNBS-treated rats), therefore only one control group and one colitis group were included. At the end of treatments, colonic tissues were excised, and scored for macroscopic damage, in accordance with the criteria previously reported. ${ }^{42}$ Macroscopic score was evaluated on the whole colon. The macroscopic damage was scored for each rat on a 0- to 6-point scale, based on the system displayed in Table S1, by two observers blinded to the treatment. At the time of experiment, the body weight, the weight of spleen and colonic length were also measured.

Effect of oral administration of 11 on body weight and spleen weight. Six days after DNBS administration, rats displayed a decrease of $63 \pm 4.1 \mathrm{~g}$ in their body weight, whereas control rats showed a weight gain $(+20 \pm 1.7 \mathrm{~g})$ (Figure $8 \mathrm{~A})$. Significant increments of body weight were observed in inflamed rats under treatment with $\mathbf{1 1}(12.5,25$ and $50 \mathrm{mg} / \mathrm{kg}), \mathrm{while} \mathrm{DEX} \mathrm{(1} \mathrm{mg/kg)} \mathrm{was}$

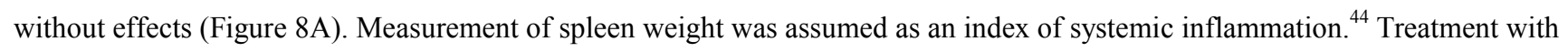
DNBS resulted in a significant increment of spleen weight $(+39.3 \%)$ (Figure 8 B). Such an increase was significantly reduced by administration of $\mathbf{1 1}(+2.2,+4.3$ and $+4.8 \%$ at $12.5,25,50 \mathrm{mg} / \mathrm{kg}$, respectively), or DEX $(+1.6 \%)$ (Figure 8B).

Effect of oral administration of 11 on colon length and macroscopic damage score. Six days after DNBS administration, the inflamed rats were characterized by a shortened colonic length (-34.4\%). The inhibition of NLRP3 inflammasome complex with 11 dose-dependently attenuated the decrease in colonic length $(-19,-13$ and $-8 \%$ at $12.5,25,50 \mathrm{mg} / \mathrm{kg}$, respectively) (Figure $8 \mathrm{C})$.

Six days after DNBS administration, the distal colon appeared thickened and ulcerated with evident areas of transmural inflammation (Figure 9). Adhesions were often present, and the bowel was occasionally dilated, with a macroscopic damage accounting for $8.6 \pm 0.6$. Rats treated with 11 displayed a significant reduction of macroscopic damage score $(4.7 \pm 0.9 \mathrm{at} 12.5 \mathrm{mg} / \mathrm{kg}, 3.1 \pm 0.7$ at $25 \mathrm{mg} / \mathrm{kg}$, and $2.8 \pm 0.4$ at $50 \mathrm{mg} / \mathrm{kg}$, Figure S5), DEX-treated animals also showed a decrease in macroscopic damage score (2.0 \pm 0.1 ) (Figures 9, S5). 


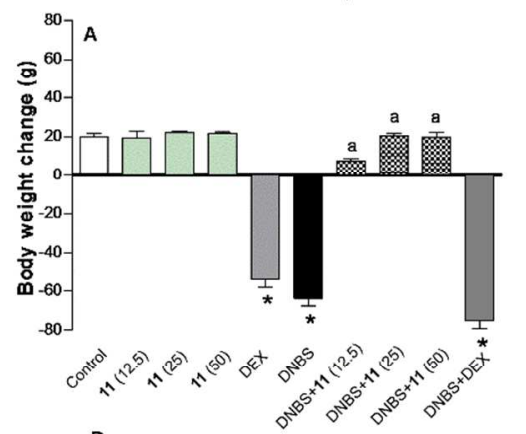

B
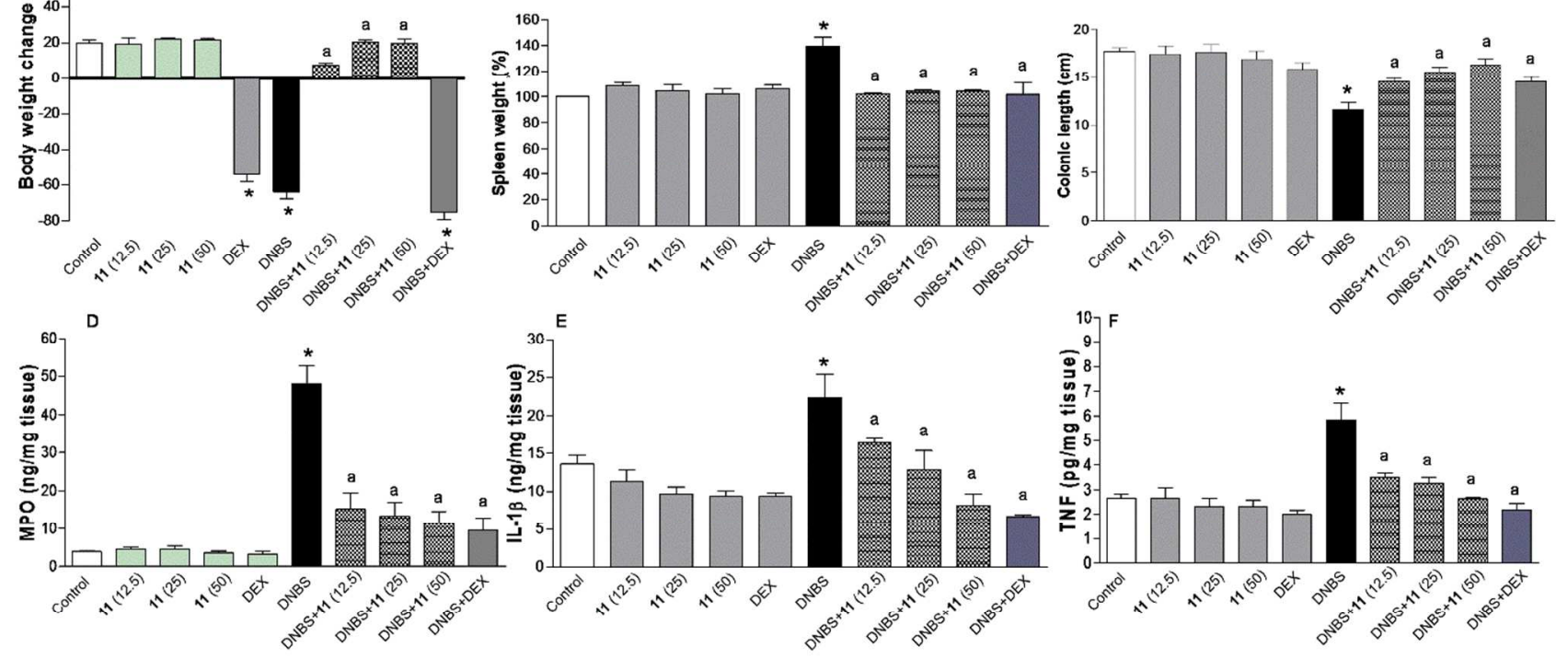

Figure 8. Effects of $11(12.5,25$, and $50 \mathrm{mg} / \mathrm{kg}$ ) or dexamethasone (DEX, $1 \mathrm{mg} / \mathrm{kg}$ ) on body weight (A), spleen weight (B), colonic length (C), tissue myeloperoxidase (MPO) (D), IL-1 $(\mathrm{E})$, and TNF levels (F) at day 6 after induction of colitis with DNBS. Each column represents the mean \pm SEM. $(n=10)$. ${ }^{\mathrm{P}}<0.05$ vs control group; ${ }^{\mathrm{P}}<0.05$, vs DNBS group

\section{Oral administration of 11 reduces colonic myeloperoxidase, IL-1ß and TNF levels in DNBS-treated rats. Biochemical assays}

were performed on specimens taken from a region of the inflamed colon immediately adjacent and distal to the gross necrotic damage. In particular, since several inflammatory mediators, including IL-1 $\beta$ and TNF cytokines, contribute to the pathogenesis of bowel inflammation, ${ }^{14,45}$ we assessed the effects of $\mathbf{1 1}$ on inflammatory infiltrate as well as IL-1 $\beta$ and TNF levels in colonic tissues from DNBS-treated rats.

The levels of tissue myeloperoxidase (MPO), regarded as a quantitative index to estimate the degree of bowel wall infiltration by inflammatory polymorphonuclear cells, were assessed as previously described. ${ }^{46}$ Specimens of colonic tissues $(30 \mathrm{mg})$ were homogenized and MPO concentration was determined by means of an enzyme-linked immunosorbent (ELISA) assay. The results were expressed as ng of MPO per mg of colonic tissue (Figure 8D). Rats with DNBS-induced colitis showed a marked increase in colonic MPO levels ( $48.1 \pm 4.7 \mathrm{ng} \mathrm{mg}^{-1}$ tissue) as compared with control animals ( $3.9 \pm 0.2 \mathrm{ng} \mathrm{mg}^{-1}$ tissue). Treatments with 12.5, 25 and $50 \mathrm{mg} / \mathrm{kg}$ of 11, or $1 \mathrm{mg} / \mathrm{kg}$ of DEX significantly prevented the increments of colonic MPO levels associated with DNBS administration (Figure 8D). IL-1 $\beta$ and TNF levels in colonic tissue homogenates were measured by ELISA as previously described $^{47}$ and expressed as ng and pg per mg of tissue, respectively (Figure 8E,F). The induction of colitis was associated with a significant increment of colonic IL-1 $\beta$ levels $(22.3 \pm 2.9 \mathrm{ng} / \mathrm{mg}$ tissue $)$ confirming previous work where increase of IL-1 $\beta$ was 
found in a mouse model of postinfectious irritable bowel syndrome. ${ }^{48}$ Treatment with $\mathbf{1 1}$ resulted in a dose-dependent decrease in tissue-associated IL-1 $\beta$ levels $(16.4 \pm 0.5,12.8 \pm 2.5$, and $6.6 \pm 0.2 \mathrm{ng} / \mathrm{mg}$ tissue at $12.5,25,50 \mathrm{mg} / \mathrm{kg}$, respectively) (Figure $8 \mathrm{E}$ ). Colonic inflammation induced by DNBS was associated also with a significant increase in tissue TNF levels $(5.9 \pm 0.6 \mathrm{pg} / \mathrm{mg}$ tissue). Treatments with 11 significantly decreased the concentration of this cytokine in colonic tissues $(3.5 \pm 0.2,3.3 \pm 0.2$, and $2.7 \pm$ $0.1 \mathrm{pg} / \mathrm{mg}$ tissue at $12.5,25,50 \mathrm{mg} / \mathrm{kg}$, respectively, Figure 8F). DEX-treated animals showed a significant decrease in IL- $1 \beta$ and TNF colonic tissue levels $(6.7 \pm 0.3 \mathrm{ng} / \mathrm{mg}$ tissue and $2.2 \pm 0.2 \mathrm{pg} / \mathrm{mg}$ tissue, respectively, Figure 8E,F). This effect confirms our in vitro data where 11 is able to block expression of both cytokines, as well as inhibiting the NLRP3 inflammasome.

Taken together, our findings show that 11 can exert beneficial effects on colitis, by reducing MPO, IL-1 $\beta$ and TNF proinflammatory cytokine levels in colonic tissues from inflamed rats, thus suggesting that the blockade of NLPR3 activation could represent a suitable pharmacological target for the management of intestinal inflammation.

Of note, 11, at the dose of $50 \mathrm{mg} / \mathrm{kg}$ was able to elicit similar beneficial effects as dexamethasone, although at a higher dose. However, 11 appears to be more advantageous than dexamethasone, since it showed a good general tolerability up to the dose of 50 $\mathrm{mg} / \mathrm{kg}$, and, most importantly, it increased significantly the body weight in inflamed rats, while dexamethasone treatment was associated with body weight loss both in control and in DNBS-treated rats. In addition, it is widely recognized that steroids are associated with several adverse effects, which limit their use as long-term therapy. Indeed, steroid-free remission presently represents a primary endpoint in the treatment of IBD. According to the obtained results, 11, in particular at the dose of $25 \mathrm{and} 50 \mathrm{mg} / \mathrm{kg}$, was able to attenuate colonic inflammation. In addition, 11 at $50 \mathrm{mg} / \mathrm{kg}$ exerted beneficial effects on colonic inflammation comparable with DEX, without deleterious effects on the body weight.

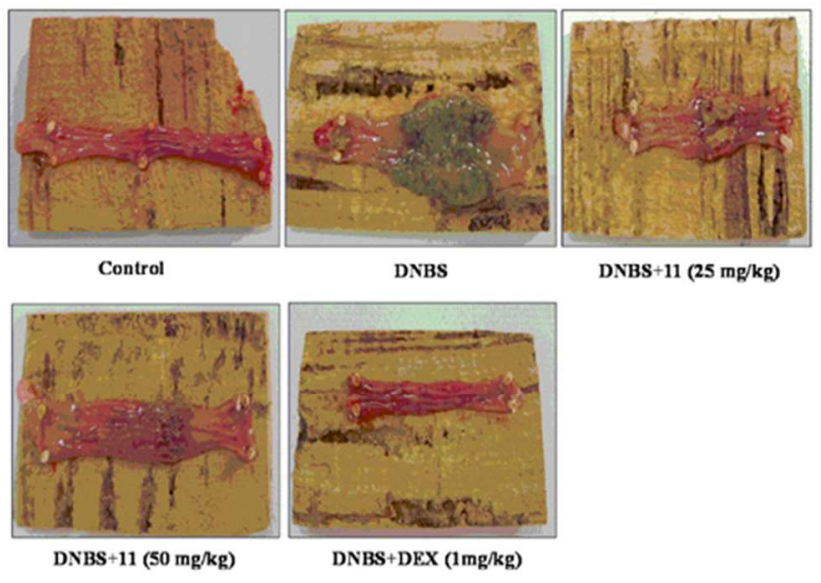

Figure 9. Macroscopic appearance of colonic tissues from control rats, DNBS-treated rats, and rats treated with DNBS and either 11 (25, and $50 \mathrm{mg} / \mathrm{kg}$ ), or dexamethasone (DEX, $1 \mathrm{mg} / \mathrm{kg}$ ).

\section{CONCLUSIONS}


Through the chemical modulation of a previously identified acrylate derivative we were able to obtain 11, a non-cytotoxic molecule able to target the activation of the NLRP3 inflammasome. Compound $\mathbf{1 1}$ was able to counteract NLRP3 activation through direct irreversible interaction with NLRP3 and partial inhibition of LPS-driven pro-inflammatory gene expression. Preliminary in vitro ADME studies showed that 11, following oral administration, is stable and is absorbed into the intestinal epithelium where it can act locally and generate the non-toxic metabolite $\mathbf{1 2}$. The in vivo ability of $\mathbf{1 1}$ to alleviate the outcomes of DNBS-induced colitis after oral administration was established. Compound 11, counteracting intestinal inflammation, may represent a lead compound for the development of novel NLRP3 inflammasome inhibitors, characterized by good degree of potency and reduced toxicity, suitable for treatment of inflammatory intestinal disorders. Further medicinal chemistry and pharmacological studies aimed at increasing NLRP3 inhibition and characterizing the in vivo pharmacokinetics and mechanism of action of the identified lead are in progress.

\section{EXPERIMENTAL SECTION}

General methods. All the reactions were monitored by TLC on Merck $60 \mathrm{~F}_{254}(0.25 \mathrm{~mm})$ plates, which were visualized by UV inspection and/or by spraying $\mathrm{KMnO}_{4}(0.5 \mathrm{~g}$ in $100 \mathrm{ml} 0.1 \mathrm{~N} \mathrm{NaOH}) . \mathrm{Na}_{2} \mathrm{SO}_{4}$ was used as drying agent for the organic phases. Flash chromatography (FC) purifications were performed using silica gel Fluka with 60 mesh particles. ${ }^{1} \mathrm{H}$ and ${ }^{13} \mathrm{C}$ NMR spectra were registered on Bruker Avance 300 spectrometer, at 300 and $75 \mathrm{MHz}$ respectively. Chemical shifts $(\delta)$ are given in ppm, calibrated to tetramethylsilane (TMS) as internal standard. Low-resolution mass spectra were recorded on a Finnigan-MAT TSQ700 in chemical ionization mode (CI) using isobutane. ESI-mass spectra were recorded on a Waters Micromass Quattro Micro equipped with an ESI source. Melting points were measured with a capillary apparatus (Büchi 540). Purity of compounds was checked by UHPLC (Perkin-Elmer) Flexar 15, equipped with UV-Vis diode array detector using an Acquity UPLC CSH Phenyl-Hexyl $1.7 \mu \mathrm{m} 2.1 \times 50 \mathrm{~mm}$ column (Waters) and $\mathrm{H}_{2} \mathrm{O} / \mathrm{CH}_{3} \mathrm{CN}$ and $\mathrm{H}_{2} \mathrm{O} / \mathrm{CH}_{3} \mathrm{OH}$ solvent systems. Detection was performed at $\lambda=200,215$ and $254 \mathrm{~nm}$. The analytical data confirmed that the purity of the products was $\geq 95 \%$. Solubility and stability of compounds in biological fluids were determined using an Acquity UPLC-MS instrument, equipped with binary solvent manager, sample manager, column manager, PDA detector (Waters) e Micromass Quattro Micro (API). The analytical conditions are reported in the following sections. Derivatives $\mathbf{1}-\mathbf{3},{ }^{25} \mathbf{1 2}^{26}$ were obtained according to the reported methods.

2-((2,4-Dichlorophenyl)(hydroxy)methyl)acrylic acid (4). To a stirred solution of 2 (229.2 $\mathrm{mg}, 0.839 \mathrm{mmol})$ in 1,4-dioxane/water $1 / 1(2 \mathrm{~mL}), 2.5 \mathrm{M} \mathrm{NaOH}$ was added and the reaction was stirred at $\mathrm{rt}$ for $18 \mathrm{~h}$. The mixture was diluted with $10 \% \mathrm{NaHCO}_{3}(15 \mathrm{~mL})$ and extracted with EtOAc $(15 \mathrm{~mL})$. The organic layer was removed and the aqueous phase was acidified with $1 \mathrm{M} \mathrm{HCl}$ and extracted with EtOAc $(3 \times 20 \mathrm{~mL})$. The organic phases were dried and evaporated. The product was purified by FC eluting with $\mathrm{CH}_{2} \mathrm{Cl}_{2} / \mathrm{MeOH}$ 9.5/0.5. Compound 4 was obtained as a white solid (203.1 mg, $0.822 \mathrm{mmol}, 98 \%$ yield). Mp: $113.1-114.4{ }^{\circ} \mathrm{C}$; MS/ESI: [M-H] ${ }^{-} 245 ;{ }^{1} \mathrm{H}$ NMR $\left(\mathrm{CDCl}_{3}\right): \delta, 7.45-7.22(\mathrm{~m}, 3 \mathrm{H}, \mathrm{ArH}), 7.14$ (br, $\left.1 \mathrm{H}, \mathrm{COOH}\right), 6.44(\mathrm{~s}, 1 \mathrm{H}, \mathrm{C}=\mathrm{CH}), 5.87(\mathrm{~s}, 1 \mathrm{H}, \mathrm{CH})$, 
$5.64(\mathrm{~s}, 1 \mathrm{H}, \mathrm{C}=\mathrm{CH}), 3.54(\mathrm{br}, 1 \mathrm{H}, \mathrm{OH}) ;{ }^{13} \mathrm{C} \mathrm{NMR}\left(\mathrm{CDCl}_{3}\right): \delta, 171.1,139.7,136.6,134.3,133.4,129.7,129.3,129.0,127.4,68.5$.

Anal. $\left(\mathrm{C}_{10} \mathrm{H}_{8} \mathrm{Cl}_{2} \mathrm{O}_{3}\right) \mathrm{C}, \mathrm{H}$

2-((2-Chlorophenyl)(3-ethoxy-3-oxopropoxy)methyl)acrylate (5). To a stirred solution of $\mathbf{1}(240.7 \mathrm{mg}, 1.00 \mathrm{mmol}) \mathrm{in} \mathrm{CH}_{3} \mathrm{CN}(2$ mL) DMAP (122.2 mg, $1.00 \mathrm{mmol})$ and DBU (0.448 mL, $3.00 \mathrm{mmol})$ were added at rt. After 10 min ethyl acrylate (1.10 mL, 10.0 mmol) was added dropwise and the mixture was stirred at $\mathrm{rt}$ for $48 \mathrm{~h}$. The reaction was diluted with $2 \mathrm{~N} \mathrm{HCl}(15 \mathrm{~mL})$ and then extracted with $\mathrm{CH}_{2} \mathrm{Cl}_{2}(3 \times 15 \mathrm{~mL})$. The combined organic phases were washed with brine $(20 \mathrm{~mL})$, dried, and evaporated. The crude mixture was purified by FC eluting with PE/EtOAc 95/5 to afford compound $\mathbf{5}$ as a colorless oil (115.2 mg, 0.338 mmol, $34 \%$ yield). Characterization in accordance with literature data. ${ }^{25}$

2-((2,4-Dichlorophenyl)(3-ethoxy-3-oxopropoxy)methyl)acrylate (6). Compound $\mathbf{6}$ was synthesized as described above starting from 2 (298.2 mg, $1.08 \mathrm{mmol})$. Colorless oil (118.3 mg, $0.315 \mathrm{mmol}, 29 \%$ yield). Characterization in accordance with literature data. $^{25}$

Ethyl 2-((2-chlorophenyl)(methoxy)methyl)acrylate (7). To a stirred solution of $\mathbf{1}(392.6 \mathrm{mg}, 1.63 \mathrm{mmol}) \mathrm{in}_{\mathrm{CH}} \mathrm{Cl}_{2}(10 \mathrm{~mL})$ $\mathrm{Ag}_{2} \mathrm{O}(755.5 \mathrm{mg}, 6.52 \mathrm{mmol})$ was added. $\mathrm{CH}_{3} \mathrm{I}(0.732 \mathrm{~mL}, 11.8 \mathrm{mmol})$ was added portionwise and the reaction was stirred at rt for 96 h. The mixture was filtered through Celite ${ }^{\circledR}$ and the solvent removed under reduced pressure. The mixture was purified by FC eluting with PE/EtOAc 98/2 to give compound 7 (168.0 mg, $0.660 \mathrm{mmol}, 40 \%$ yield) as a colorless oil. MS/ESI [M+H] ${ }^{+} 255$; ${ }^{1} \mathrm{H}$ $\operatorname{NMR}\left(\mathrm{CDCl}_{3}\right): \delta, 7.51-7.11(\mathrm{~m}, 4 \mathrm{H}, \mathrm{ArH}), 6.39(\mathrm{~s}, 1 \mathrm{H}, \mathrm{C}=\mathrm{CH}), 5.69(\mathrm{~s}, 1 \mathrm{H}, \mathrm{C}=\mathrm{CH}), 5.61(\mathrm{~s}, 1 \mathrm{H}, \mathrm{CH}), 4.18(\mathrm{q}, 2 \mathrm{H}, J=7.1 \mathrm{~Hz}$ $\left.\mathrm{OCH}_{2}\right), 3.38\left(\mathrm{~s}, 3 \mathrm{H}, \mathrm{OCH}_{3}\right), 1.24\left(\mathrm{t}, 3 \mathrm{H}, J=7.1 \mathrm{~Hz}, \mathrm{CH}_{3}\right) ;{ }^{13} \mathrm{C} \mathrm{NMR}\left(\mathrm{CDCl}_{3}\right): \delta, 166.2,140.5,137.3,134.6,129.9,129.5,128.8$, 127.4, 126.7, 77.6, 61.2, 58.1, 14.5. Anal. $\left(\mathrm{C}_{13} \mathrm{H}_{15} \mathrm{ClO}_{3}\right) \mathrm{C}, \mathrm{H}$

Ethyl 3-(acetoxy(2-chlorophenyl)methyl)-2-oxobut-3-enoate (8). To a stirred solution of 1 (2.07 g, 8.60 mmol) and DMAP (210.2 $\mathrm{mg}, 1.72 \mathrm{mmol})$ in $\mathrm{CH}_{2} \mathrm{Cl}_{2}(40 \mathrm{~mL})$ acetic anhydride $(0.974 \mathrm{~mL}, 10.3 \mathrm{mmol})$ was added portionwise in $1 \mathrm{~h}$. The reaction was stirred at $\mathrm{rt}$ for $1 \mathrm{~h}$. The mixture was washed with water $(3 \times 30 \mathrm{~mL}), 10 \% \mathrm{NaHCO}_{3}(10 \mathrm{~mL})$, and brine $(15 \mathrm{~mL})$. The organic phase was dried, and the solvent removed under reduced pressure. The crude product was purified by FC eluting with PE/EtOAc 9/1 to obtain compound 8 (2.14 g, $7.57 \mathrm{mmol}, 88 \%$ yield) as a colorless oil. MS/CI (isobutane): $[\mathrm{M}+\mathrm{H}]^{+} 283 ;{ }^{1} \mathrm{H}$ NMR $\left(\mathrm{CDCl}_{3}\right): \delta, 7.47-7.26(\mathrm{~m}$, 4H, ArH), $7.06(\mathrm{~s}, 1 \mathrm{H}, \mathrm{CH}), 6.47(\mathrm{~s}, 1 \mathrm{H}, \mathrm{C}=\mathrm{CH}), 5.63(\mathrm{~s}, 1 \mathrm{H}, \mathrm{C}=\mathrm{CH}), 4.19\left(\mathrm{q}, 2 \mathrm{H}, \mathrm{J}=7.1 \mathrm{~Hz}, \mathrm{OCH}_{2}\right), 2.12\left(\mathrm{~s}, 3 \mathrm{H}, \mathrm{COCH}_{3}\right), 1.23$ $\left(\mathrm{t}, 3 \mathrm{H}, J=7.1 \mathrm{~Hz}, \mathrm{CH}_{3}\right) ;{ }^{13} \mathrm{C} \mathrm{NMR}\left(\mathrm{CDCl}_{3}\right): \delta, 169.6,165.3,138.9,135.8,134.1,130.2,130.0,128.9,127.8,127.3,70.5,61.5,21.1$, 14.4. Anal. $\left(\mathrm{C}_{14} \mathrm{H}_{15} \mathrm{ClO}_{4}\right) \mathrm{C}, \mathrm{H}$.

Ethyl 2-((allyloxy)(2-chlorophenyl)methyl)acrylate (9). To a stirred solution of $\mathbf{8}(299.7 \mathrm{mg}, 1.06 \mathrm{mmol})$ in $\mathrm{dry} \mathrm{THF}(5 \mathrm{~mL})$ DABCO (237.8 mg, $2.12 \mathrm{mmol})$ was added and the solution stirred at $\mathrm{rt}$ for $10 \mathrm{~min}$. 2-Propenol $(0.198 \mathrm{~mL}, 3.18 \mathrm{mmol})$ was then added and the reaction was stirred at $60{ }^{\circ} \mathrm{C}$ for $48 \mathrm{~h}$. The mixture was diluted with water $(20 \mathrm{~mL})$ and extracted with EtOAc $(3 \mathrm{x} 20$ $\mathrm{mL})$, washed with brine $(15 \mathrm{~mL})$, dried, and the solvent removed under reduced pressure. The crude product was purified by FC eluting with PE/EtOAc 95/5 to obtain compound 9 (193.4 mg, $0.689 \mathrm{mmol}, 65 \%$ yield) as a colorless oil. MS/ESI: [M+H] ${ }^{+} 281 ;{ }^{1} \mathrm{H}$ $\operatorname{NMR}\left(\mathrm{CDCl}_{3}\right): \delta, 7.45-7.14(\mathrm{~m}, 4 \mathrm{H}, \mathrm{ArH}), 6.39(\mathrm{~s}, 1 \mathrm{H}, \mathrm{C}=\mathrm{CH}), 5.99-5.87\left(\mathrm{~m}, 1 \mathrm{H}, \mathrm{HC}=\mathrm{CH}_{2}\right), 5.76(\mathrm{~s}, 1 \mathrm{H}, \mathrm{CH}), 5.72(\mathrm{~s}, 1 \mathrm{H}$, 
$\mathrm{C}=\mathrm{CH}), 5.30-5.14\left(\mathrm{~m}, 2 \mathrm{H}, \mathrm{HC}=\mathrm{CH}_{2}\right), 4.18\left(\mathrm{q}, 2 \mathrm{H}, \mathrm{J}=7.1 \mathrm{~Hz}, \mathrm{OCH}_{2} \mathrm{CH}_{3}\right), 4.06-4.00\left(\mathrm{~m}, 2 \mathrm{H}, \mathrm{OCH}_{2}\right), 1.23\left(\mathrm{t}, 3 \mathrm{H}, J=7.1 \mathrm{~Hz}, \mathrm{CH}_{3}\right)$; ${ }^{13} \mathrm{C}$ NMR $\left(\mathrm{CDCl}_{3}\right): \delta, 165.7,140.4,137.2,134.4,133.9,129.5,129.0,128.7,126.9,126.4,117.1,75.0,70.7,60.8,14.1$.

Ethyl 2-(2-chlorophenyl)-2,5-dihydrofuran-3-carboxylate (10). To a stirred solution of $9\left(80.7 \mathrm{mg}, 0.287 \mathrm{mmol}^{2}\right.$ in dry $\mathrm{CH}_{2} \mathrm{Cl}_{2}$ (12 mL) under $\mathrm{N}_{2}$, 1,3-bis-(2,4,6-trimethylphenyl)-2-imidazolidinylidene)dichloro(o-isopropoxyphenylmethylene) ruthenium (4.0 $\mathrm{mg}$ ) was added. The reaction was heated at reflux for $3 \mathrm{~h}$ and then at $\mathrm{rt}$ for $16 \mathrm{~h}$. The solvent was removed under reduced pressure and the crude product was purified by FC eluting with PE, then PE/EtOAc 98/2. Compound 10 (30.9 mg, $0.123 \mathrm{mmol}, 43 \%$ yield) was obtained as a yellow solid. MS/ESI $[\mathrm{M}+\mathrm{H}]^{+} 253 ;{ }^{1} \mathrm{H} \mathrm{NMR}\left(\mathrm{CDCl}_{3}\right): \delta, 7.48-7.15(\mathrm{~m}, 4 \mathrm{H}, \mathrm{ArH}), 7.14-7.00(\mathrm{~m}, 1 \mathrm{H}, \mathrm{C}=\mathrm{CH})$, 6.45-6.37 (m, 1H, CH), 5.05-4.66 (m, 2H, $\left.\mathrm{OCH}_{2}\right), 4.06\left(\mathrm{q}, 2 \mathrm{H}, J=7.3 \mathrm{~Hz}, \mathrm{OCH}_{2} \mathrm{CH}_{3}\right), 1.13\left(\mathrm{t}, 3 \mathrm{H}, J=7.1 \mathrm{~Hz}, \mathrm{CH}_{3}\right) ;{ }^{13} \mathrm{C} \mathrm{NMR}$ $\left(\mathrm{CDCl}_{3}\right): \delta, 162.5,140.0,138.1,135.4,134.3,130.1,129.8,129.2,127.3,83.7,75.6,61.1,14.4$.

Ethyl 2-(2-chlorobenzyl)acrylate (11). To a stirred solution of 8 (968 mg, $3.43 \mathrm{mmol})$ and DABCO (384 mg, $3.43 \mathrm{mmol})$ in $\mathrm{THF} / \mathrm{H}_{2} \mathrm{O} 1 / 1(40 \mathrm{~mL}), \mathrm{NaBH}_{4}(129 \mathrm{mg}, 3.43 \mathrm{mmol})$ was added portionwise and the reaction was stirred at $\mathrm{rt}$ for $1 \mathrm{~h}$. The mixture was diluted with water $(30 \mathrm{~mL})$, and extracted with EtOAc $(3 \times 50 \mathrm{~mL})$. The organic phase was washed with brine $(50 \mathrm{~mL})$, dried, and evaporated under reduced pressure. After purification by FC eluting with PE/EtOAc 95/5 compound 11 (649 mg, 2.88 mmol, $84 \%$ yield) was obtained as a colorless oil. MS/CI (isobutane): $[\mathrm{M}+\mathrm{H}]^{+} 225 ;{ }^{1} \mathrm{H} \mathrm{NMR}\left(300 \mathrm{MHz}, \mathrm{CDCI}_{3}\right) \delta=7.50-6.99(\mathrm{~m}, 4 \mathrm{H})$, $6.27(\mathrm{~d}, J=1.1 \mathrm{~Hz}, 1 \mathrm{H}), 5.33(\mathrm{~d}, J=1.1 \mathrm{~Hz}, 1 \mathrm{H}), 4.22(\mathrm{q}, J=7.1 \mathrm{~Hz}, 2 \mathrm{H}), 3.76(\mathrm{~s}, 2 \mathrm{H}), 1.29(\mathrm{t}, J=7.1 \mathrm{~Hz}, 3 \mathrm{H}) ;{ }^{13} \mathrm{C} \mathrm{NMR}(75 \mathrm{MHz}$ $\left.\mathrm{CDCl}_{3}\right) \delta=166.8,138.4,136.4,134.5,131.2,129.6,127.9,126.8,126.3,60.4,35.4,14.2$. Characterization was in accordance with literature data. ${ }^{26}$

Ethyl 3-(2-chlorophenyl)-2-methylpropanoate (13). To a stirred solution of $\mathbf{1}(240.7 \mathrm{mg}, 1.00 \mathrm{mmol})$ in abs EtOH (5 mL), $10 \%$ $\mathrm{Pd} / \mathrm{C}(24.1 \mathrm{mg})$ was added. The atmosphere was then changed to $\mathrm{H}_{2}$ and the mixture was stirred at $\mathrm{rt}$ for $30 \mathrm{~min}$. The reaction was filtered through Celite ${ }^{\circledR}$ and the filtrate evaporated to obtain 13 as a pale yellow oil (219.2 mg, 0.967 mmol, 97\% yield); MS/CI (isobutane): $[\mathrm{M}+\mathrm{H}]^{+} 227 ;{ }^{1} \mathrm{H}$ NMR $\left(\mathrm{CDCl}_{3}\right): \delta, 7.37-7.11(\mathrm{~m}, 4 \mathrm{H}, \mathrm{ArH}), 4.07\left(\mathrm{q}, 2 \mathrm{H}, J=7.0 \mathrm{~Hz}, \mathrm{OCH}_{2}\right), 3.01(\mathrm{dd}, 1 \mathrm{H}, J=11.9,5.5$ $\mathrm{Hz}, \mathrm{CH}), 2.78-2.56\left(\mathrm{~m}, 2 \mathrm{H}, \mathrm{CH}_{2}\right), 1.29-1.08\left(\mathrm{~m}, 6 \mathrm{H}, 2 \mathrm{CH}_{3}\right) ;{ }^{13} \mathrm{C} \mathrm{NMR}\left(\mathrm{CDCl}_{3}\right): \delta, 178.2,138.3,135.1,131.1,130.6,128.8,127.3$, 61.8, 41.7, 36.4, 16.7, 14.7. Anal. $\left(\mathrm{C}_{12} \mathrm{H}_{15} \mathrm{ClO}_{2}\right) \mathrm{C}, \mathrm{H}$

3-(2-Chlorophenyl)-2-methylpropanoic acid (14). Compound 14 was obtained starting from 13 (119.5 mg, $0.527 \mathrm{mmol}) \mathrm{using}$ the same procedure described for 4. Pale yellow solid (100.5 mg, $0.506 \mathrm{mmol}, 96 \%$ yield); Mp: 36.7 - $37.4{ }^{\circ} \mathrm{C} . \mathrm{MS} / \mathrm{ESI}:$ [M-H] ${ }^{-}$ 197; ${ }^{1} \mathrm{H} \mathrm{NMR}\left(\mathrm{CDCl}_{3}\right): \delta, 11.63(\mathrm{bs}, 1 \mathrm{H}, \mathrm{COOH}), 7.38-7.24(\mathrm{~m}, 4 \mathrm{H}, \mathrm{ArH}), 3.07$ (dd, 1H, J=13.0, 6.6 Hz, CH), 2.85-2.56 (m, $2 \mathrm{H}$, $\left.\mathrm{CH}_{2}\right), 1.16(\mathrm{~d}, 3 \mathrm{H}, J=6.6 \mathrm{~Hz} \mathrm{CH}) ;{ }^{13} \mathrm{C} \mathrm{NMR}\left(\mathrm{CDCl}_{3}\right): \delta, 182.8,139.4,138.5,135.2,129.4,128.8,126.8,41.6,39.7,16.7$. Anal. $\left(\mathrm{C}_{10} \mathrm{H}_{11} \mathrm{ClO}_{2}\right) \mathrm{C}, \mathrm{H}$.

Biological screening

Reactivity as Michael acceptor, modification of human serum albumin, cytotoxicity in THP-1 cells, and Antipyroptotic activity were performed according to the previously reported methods. ${ }^{25,26}$ 
Measurement of NLRP3-ATPase Activity: Human recombinant NLRP3 (0.105 $\mu \mathrm{g}$; BPS Bioscience, San Diego, USA) was incubated with the assessed compounds in the reaction buffer $(20 \mathrm{mM}$ Tris- $\mathrm{HCl}$, $\mathrm{pH} 7.8,133 \mathrm{mM} \mathrm{NaCl}, 20 \mathrm{mM} \mathrm{MgCl}$, $3 \mathrm{mM} \mathrm{KCl}$, $0.56 \mathrm{mM}$ EDTA, DMSO $0.5 \%)$ for $15 \mathrm{~min}$ at $37^{\circ} \mathrm{C}$. ATP $(250 \mu \mathrm{M}$, Ultra Pure ATP $)$ was added and the reaction mixtures were further incubated for $40 \mathrm{~min}$ at $37^{\circ} \mathrm{C}$. The hydrolysis of ATP by NLRP3 was determined by a luminescent ADP detection performed with ADP-Glo Kinase Assay (Promega, Madison, USA) according to the manufacturer's protocol.

Irreversible inhibition of NLRP3 ATPase activity. NALP3 (CIAS1), His-FLAG-tags protein was immobilized on a well plate using Flag Ab. Flag Ab (250 ng) diluted in PBS (pH 7.4), was added in each well of a Maxisorp-96-well plate-white and incubated for $3 \mathrm{~h}$ at $4{ }^{\circ} \mathrm{C}$. After washing the remaining protein binding sites of the plate were saturated with blocking solution containing bovine serum albumin (BSA) $2 \%$ overnight at $4{ }^{\circ} \mathrm{C}$. The next day NALP3 protein was bound (105 ng per well) incubating the protein diluted in the ATPase assay buffer for 3 hours at $4{ }^{\circ} \mathrm{C}$. After washing the activity of NALP3-immobilized protein and the inhibition of compounds 11 and 13 were measured. Compounds 11 and 13 (100 $\mu \mathrm{M}$ final concentration, 2\% DMSO) were added to wells containing immobilized NALP3 protein and pre-incubated for 55 min at $37^{\circ} \mathrm{C}$ to mimic normal experiment time $(15$ min preincubation + 40 min incubation with ATP); in the control wells a mixture of buffer and DMSO was added. After pre-incubation time the wells were washed three times with reaction buffer and ATP $(250 \mu \mathrm{M})$ was added for 40 min at $37{ }^{\circ} \mathrm{C}$. ADP formation was measured with ADP-Glo-Assay using the reported method. ${ }^{26}$ The activity level of the enzyme was comparable to that obtained with nonimmobilized NALP3 protein. An experiment of ATPase activity without washing step was also repeated incubating 11 and $\mathbf{1 3}$ on NLRP3 immobilized protein to confirm percentage of inhibition of compounds $\mathbf{1 1}$ and $\mathbf{1 3}$ as previously measured. The total amount of immobilized NALP3 was also checked by ELISA using an anti-His Tag antibody and equal amount of enzyme were detected in all labeled wells $(99.6 \pm 0.7$ mean of $\%$ vs control \pm S.D. $)$

Solubility of 11 in pH 7.4 PBS. Compound $11(1 \mathrm{mg})$ was added to $1 \mathrm{~mL}$ of phosphate buffer solution $(10 \mathrm{mM} \mathrm{with} \mathrm{KCl} 10 \mathrm{mM}$, $\mathrm{pH}$ 7.4). The samples were shaked with an orbital shaker at $25^{\circ} \mathrm{C}$ for $24 \mathrm{~h}$. These suspensions were filtered through a PES $0.2 \mu \mathrm{m}$ filter (Agilent) and the solutions were chromatographically analyzed.

The concentration of compounds in the PBS was quantified by UHPLC-MS using an Acquity Waters C18 BEH (1.7 $\mu \mathrm{m}, 2.1 \mathrm{x} 50$ $\mathrm{mm}$ ) column. The samples were analyzed using an isocratic method employing a mobile phase consisting of acetonitrile/water + $0.1 \%$ formic acid (60/40). The flow rate is $0.5 \mathrm{~mL} / \mathrm{min}$. The injection volume is $5 \mu \mathrm{L}$. The column effluent was monitored at $\lambda=$ $235 \mathrm{~nm}$ referenced against $360 \mathrm{~nm}$. The linearity of the calibration curves was determined in a concentration range of $10-500 \mu \mathrm{M}$ $\left(r^{2}>0.99\right)$. Data analysis was performed by using Mass Linx software (Waters).

Stability of 11 in simulated gastric fluid and simulated intestinal fluid. In vitro simulated digestion was performed according to the reported method with some modifications. ${ }^{36}$ A simulated gastric fluid (SGF, pH 2) containing pepsin (3.2 mg/mL) and a simulated intestinal fluid (SIF, pH 7) containing pancreatin (8xUSP; $2 \mathrm{mg} / \mathrm{mL})$ were prepared as described previously. ${ }^{36}$ Compound 11 (1,56 mg) was suspended into $100 \mu \mathrm{L}$ of olive oil (dose and vehicle used for oral rat administration) and mixed with $100 \mu \mathrm{L}$ of SGF. The mixture was incubated at $37{ }^{\circ} \mathrm{C}$ in a shaker at $350 \mathrm{rpm}$ for $2 \mathrm{~h}$. For intestinal phase $200 \mu \mathrm{L}$ of SIF were added at the sam- 
ples derived from gastric phase and they were incubated at $37^{\circ} \mathrm{C}$ in a shaker at $350 \mathrm{rpm}$ for further $2 \mathrm{~h}$. For both gastric and intestinal phases four different times were analyzed $(0,30,60$, and $120 \mathrm{~min})$. A dedicated sample was prepared for each incubation time considered. At each time-point $200 \mu \mathrm{L}$ of acetonitrile were added and mixed for $30 \mathrm{~min}$. The samples were then centrifuged (3200 $\mathrm{rpm}, 10 \mathrm{~min}$ ), and the water/acetonitrile phase was diluted with acetonitrile to a theoretic $0.1 \mathrm{mM}$ concentration and immediately analyzed by UHPLC-MS. ${ }^{37}$ Compounds concentration in the gastro intestinal fluid was quantified by UHPLC-MS using a Zorbax Eclipse C18 (4.6 x $150 \mathrm{~mm}$ ) column. The samples were analyzed using an isocratic method employing a mobile phase consisting of acetonitrile/water $+0.1 \%$ formic acid $(80 / 20)$. The flow rate is $0.5 \mathrm{~mL} / \mathrm{min}$. The injection volume is $5 \mu \mathrm{L}$. The column effluent was monitored at $\lambda=235 \mathrm{~nm}$ referenced against $360 \mathrm{~nm}$. Data analysis was performed by using Mass Linx software (Waters). To check for chemical stability, a suspension of compound $\mathbf{1 1}$ in olive oil was also incubated with water alone, acidic solution (pH 2) without pepsin, and intestinal solution ( $\mathrm{pH} 7$ ) without pancreatin. Each experiment was independently repeated at least three times.

Permeation measurements across excised rat small intestine. Ex vivo absorption evaluation was carried out by permeation measurements in excised rat small intestine. Male Sprague Dawley rats (200-250 g) were anaesthetized with isoflurane, decapitated and exsanguinated. Freshly excised rat duodenum, jejunum and ileum tissues were washed with Krebs-Ringer buffer (KRB) and cut into pieces of 4-5 cm. A suspension $(0.2 \mathrm{~mL})$ containing compound 11 (12.5 mg / $0.2 \mathrm{~mL}$ olive oil) was syringed into intestinal sacs; the filled tissues were incubated in oxygenated $\mathrm{KRB}(10 \mathrm{~mL})$ at $37{ }^{\circ} \mathrm{C}$ with smooth shaking. Sample solution $(0.5 \mathrm{~mL})$ was withdrawn from the serosal side at fixed time intervals up to 120 minutes and replaced with fresh buffer. Tests were performed in triplicate for each compound on the three different intestinal segments from three different rats. Compound concentration in the incubation buffer was quantified by UHPLC-MS using a Zorbax Eclipse C18 (4.6 x $150 \mathrm{~mm})$ column. The samples were analyzed using an isocratic method employing a mobile phase consisting of acetonitrile $+0.1 \%$ formic acid $/$ water $+0.1 \%$ formic acid $(80 / 20)$ (flow rate $0.5 \mathrm{~mL} / \mathrm{min}$ ). The column effluent was monitored at $\lambda=235 \mathrm{~nm}$. Quantitation was done using calibration curves of compound 12 chromatographed under the same conditions. The linearity of the calibration curves was determined in a concentration range of $2.5-500 \mu \mathrm{M}\left(\mathrm{r}^{2}>0.99\right)$. Data analysis was performed by using Mass Linx software (Waters).

Microsomal stability assay. Compounds 11 and 12 in DMSO solution (final concentration $100 \mu \mathrm{M}$ ) were incubated in a shaker at $350 \mathrm{rpm}$ at $37^{\circ} \mathrm{C}$ for $120 \mathrm{~min}$ in $100 \mathrm{mM}$ phosphate buffer (pH 7.4), with rat liver microsomes $(0.5 \mathrm{mg}$ proteins / $\mathrm{mL})$, in the presence of a NADPH-generating system at a final volume of $1 \mathrm{~mL}$ (DMSO did not exceed 2\%). The reaction was stopped at different times $(0,15,30,60$, and $120 \mathrm{~min})$ by adding to $100 \mu \mathrm{L}$ of incubation mixture, $100 \mu \mathrm{L}$ of acetonitrile and cooling in ice. The samples were then centrifuged (3200 rpm, $10 \mathrm{~min}$ ) and analyzed by UHPLC-MS. Compounds concentration in the incubation microsomes was quantified by UHPLC-MS using a Zorbax Eclipse C18 (4.6 x $150 \mathrm{~mm}$ ) column. The samples were analyzed using an isocratic method employing a mobile phase consisting of acetonitrile/water $+0.1 \%$ formic acid (80/20) for compound $\mathbf{1 1}$ and of acetonitrile/water $+0.1 \%$ formic acid (70/30) for compound $\mathbf{1 2}$. The flow rate is $0.5 \mathrm{~mL} / \mathrm{min}$. The injection volume is $5 \mu \mathrm{L}$. The column effluent was monitored at $\lambda=235 \mathrm{~nm}$ referenced against $360 \mathrm{~nm}$. The linearity of the calibration curves was determined in a concentration range of 2.5-500 $\mu \mathrm{M}\left(\mathrm{r}^{2}>0.99\right)$. Data analysis was performed by using Mass Linx software (Waters). To check for 
microsomal or NADPH-generating system interferences in analytical analysis, samples containing microsomes without compounds and boiled microsomes were also incubated and analyzed. Finally, microsomes without NADPH generating system were incubated to analyze the presence of non-cytochrome-dependent reactions. Each experiment was independently repeated at least three times.

Cells and treatments. Primary BMDMs were in vitro differentiated from C57BL/6 mice with $20 \%$ of L-cell media as reported elsewhere, ${ }^{49}$ primed with LPS $(1 \mu \mathrm{g} / \mathrm{mL}, 3 \mathrm{~h}$, Sigma) and subsequent treated with the indicated concentrations of dexamethasone (Sigma), Bay 11-7082 (Sigma), dimethylfumarate (Sigma) or compound 11 or vehicle $(1 \mathrm{~h})$, and finally stimulated with either ATP (5 mM, $30 \mathrm{~min}$, Sigma) or nigericin (10 $\mathrm{MM}, 30 \mathrm{~min}$, Sigma). Immortalized BMDMs from NLRP3-deficient mice were a kind gift of K. A. Fitzgerald. ${ }^{50}$ Retroviral Tet-ON 3G inducible system (Clontech) was used to introduce YFP-NLRP3-Luc gene. First, cells were transduced with tetracycline transactivator-encoding retrovirus. Selected clone was further transduced by retrovirus encoding the YFP(Nt)-NLRP3-Luc(Ct) fusion reporter or empty vector. After selection, these macrophages were treated with doxycycline $(0.5 \mu \mathrm{g} / \mathrm{ml}$, Sigma) to induce the expression of YFP-NLRP3-Luc and LPS (100 $\mathrm{ng} / \mathrm{mL})$ for $24 \mathrm{~h}$ and subsequently activated with nigericin $(10 \mu \mathrm{M}, 1 \mathrm{~h})$ to assess functionality of the NLRP3 BRET sensor. 293 cells stably expressing the BRET sensor YFPNLRP3-Luc receptor were maintained in DMEM supplemented with 10\% FCS, 2 mM Glutamax, and 1\% penicillin-streptomycin.

Bioluminescence resonance energy transfer measurements. 293 cells expressing the NLRP3 BRET sensor were plated on a poly-L-lysine-coated white opaque 96-well plate; after adhesion, cells were incubated for $15 \mathrm{~h}$ with the indicated doses of compound $\mathbf{1 1}$ or vehicle, washed with PBS with calcium and magnesium, and BRET readings were performed immediately after the addition of $5 \mu \mathrm{M}$ coelenterazine-H substrate (Invitrogen). Signals were detected with two filter settings (Renilla-luciferase (Luc) filter $[485 \pm 20 \mathrm{~nm}]$ and YFP filter $[530 \pm 25 \mathrm{~nm}])$ at $37{ }^{\circ} \mathrm{C}$ using the Synergy Mx plate reader (BioTek) as described before. ${ }^{33,34}$

Lactate dehydrogenase-release measurements. The presence of lactate dehydrogenase (LDH) in the medium was measured using the Cytotoxicity Detection kit (Roche), following the manufacturer's instructions. It was expressed as the percentage of the total amount of LDH in the cells.

Caspase-1 activity assays. Caspase-1 activity was measured by incubating human recombinant caspase-1 (10 U, MerckMillipore) with different concentrations of 11 or the caspase-1 inhibitor Ac-YVAD-CMK (100 $\mu$ M, Merck-Millipore) and monitoring the cleavage of the fluorescent substrate z-YVAD-AFC (Promokine) at $400 \mathrm{~nm}$ and $505 \mathrm{~nm}$ with a Synergy Mx plate reader (BioTek) for $3 \mathrm{~h}$ at 10 min intervals. Results are presented as the relative fluorescence units (RFU) per min of reaction.

Quantitative reverse transcriptase-PCR analysis. The detailed methods used for quantitative reverse transcriptase-PCR have been described previously. ${ }^{51}$ Specific primers were purchased from Qiagen (QuantiTech Primer Assays). For each primer set, the efficiency was $>95 \%$, and a single product was obtained on melt curve analysis. The presented relative gene expression levels were calculated using the $2^{-\Delta \mathrm{Ct}}$ method normalizing to Hrpt expression levels for each treatment.

ELISA and Western blot to detect IL-1 $\beta$ release and caspase-1 activation from macrophages. IL- $1 \beta$ and caspase- 1 were detected from clarified macrophage supernatants using standard procedure for Western blot. ${ }^{49}$ ELISA kits for mouse IL-1 $\beta$ were from R\&D Systems and were used according to the manufacturer's instructions. 
Animals. Male Sprague-Dawley rats, $200-250 \mathrm{~g}$ body weight, were used throughout the study. The animals were fed standard laboratory chow and tap water ad libitum and were not employed for at least one week after their delivery to the laboratory. They were housed, three in a cage, in temperature-controlled rooms on a 12 -h light cycle at $22-24{ }^{\circ} \mathrm{C}$ and $50-60 \%$ humidity. Their care and handling were in accordance with the provisions of the European Community Council Directive 86-609, recognized and adopted by the Italian Government. All efforts were made to minimize animals' suffering and to reduce the number of animals used.

Induction of Colitis and Drug Treatments. Colitis was induced in accordance with the method previously described. ${ }^{42}$ During a short anesthesia with isoflurane (Abbott, Rome, Italy), $15 \mathrm{mg}$ of 2,4-dinitrobenzenesulfonic acid (DNBS) in $0.25 \mathrm{~mL}$ of $50 \%$ ethanol was administered intrarectally via a polyethylene PE-60 catheter inserted $8 \mathrm{~cm}$ proximal to the anus. Control rats received 0.25 $\mathrm{mL}$ of $50 \%$ ethanol. Animals underwent subsequent experimental procedures 6 days after DNBS administration to allow a full development of histologically evident colonic inflammation. Test drugs were administered by intragastric route for 6 days, starting the same day of colitis induction. DNBS-untreated and DNBS-treated animals were assigned to the following treatment groups: 11 $(12.5,25,50 \mathrm{mg} / \mathrm{kg} / \mathrm{day})$ or dexamethasone (DEX, $1 \mathrm{mg} / \mathrm{kg} / \mathrm{day}) .11$ and dexamethasone were suspended in olive oil and $1 \%$ methylcellulose, respectively, and administered in a volume of $0.2 \mathrm{~mL} /$ rat. DNBS-untreated animals (control group) and DNBStreated rats (colitis group) received drug vehicle to serve as controls. Body weight was monitored daily starting from the onset of drug treatments.

Effective doses of $\mathbf{1 1}$ were selected by preliminary experiments designed to assay increasing doses of this compound $(6,12.5,25$, 50 and $100 \mathrm{mg} / \mathrm{kg}$ ) on food intake, body weight, spleen weight, and macroscopic score in the model of DNBS-induced colitis. The dose of dexamethasone was selected on the basis of a previous study performed on a rat model of colitis. ${ }^{43}$ Macroscopic score was evaluated on the whole colon, while biochemical assays were performed on specimens taken from a region of the inflamed colon immediately adjacent and distal to the gross necrotic damage.

Assessment of Colitis. At the end of treatments, colonic tissues were excised, rinsed with saline, and scored for macroscopic damage. The macroscopic damage was scored on a 0- to 6-point scale, based on the system illustrated in Table S1. The presence of adhesions between colonic tissue and other organs ( 0 , none; 1 , minor; 2 , major adhesions) and the consistency of colonic fecal material ( 0 , formed; 1 , loose; 2 , liquid stools) were also scored.

Evaluation of tissue myeloperoxidase levels (MPO). MPO, regarded as a quantitative index to estimate the degree of bowel wall infiltration by inflammatory polymorphonuclear cells, was assessed as described. ${ }^{46}$ Specimens of colonic tissues $(30 \mathrm{mg})$ were homogenized on ice with a polytron homogenizer (QIAGEN, Milan, Italy) in $0.6 \mathrm{~mL}$ of ice-cold lysis buffer containing $200 \mathrm{mM}$ $\mathrm{NaCl}, 5 \mathrm{mM}$ EDTA, $10 \mathrm{mM}$ Tris, $10 \%$ glycerine, $1 \mathrm{mM}$ phenylmethylsulfonyl fluoride, $1 \mathrm{~g} / \mathrm{mL}$ leupeptin and $28 \mathrm{~g} / \mathrm{mL}$ aprotinin (pH 7.4). The homogenate was centrifuged 2 times at $4{ }^{\circ} \mathrm{C}$ for $15 \mathrm{~min}$ at $1,500 \mathrm{~g}$. The supernatant was diluted $1: 5$ and used for the determination of MPO concentration by means of an enzyme-linked immunosorbent assay (ELISA) (Hycult Biotech, Uden, Netherlands). The results were expressed as nanograms of MPO per milligram of colonic tissue. 
Evaluation of tissue TNF and IL-1 $\beta$ levels. TNF and IL-1 $\beta$ levels in colonic tissues were measured by an ELISA kit (Abcam), as previously described. ${ }^{47}$ For this purpose, colonic tissue samples, stored previously at $-80{ }^{\circ} \mathrm{C}$, were weighed, thawed, and homogenized in $0.4 \mathrm{~mL}$ of $\mathrm{pH} 7.2 \mathrm{PBS} / 20 \mathrm{mg}$ of tissue at $4{ }^{\circ} \mathrm{C}$, and centrifuged at $10,000 \mathrm{~g}$ for $5 \mathrm{~min}$. Aliquots (100 $\left.\mu \mathrm{L}\right)$ of the supernatants were then used for assay. Tissue TNF and IL-1 $\beta$ levels were expressed as pg and ng per mg of tissue, respectively.

Statistical analysis. The results are presented as mean \pm SEM. unless otherwise stated. The significance of differences was evaluated by Student t-test for unpaired data or one-way analysis of variance (ANOVA) followed by post-hoc analysis with StudentNewman-Keuls or Bonferroni tests. P values $<0.05$ were considered significantly different. All statistical procedures were performed by commercial software (GraphPad Prism, version 3.0 from GraphPad Software Inc., San Diego, CA, USA).

\section{ANCILLARY INFORMATION}

Supporting information: Molecular formula strings (.CSV file); structures of NLRP3 pathway inhibitors studied in IBD models and relevant references, reactivity of $\mathbf{1 1}$ with cysteamine, stability of $\mathbf{1 1}$ in human serum; BRET assay approach; table of criteria used for scoring of colonic macroscopic damage, and damage-score determination in 11-treated animals. The Supporting Information is available free of charge on the ACS Publications website at DOI:........

\section{Corresponding Author information}

*M.B. e-mail, massimo.bertinaria@unito.it; phone, +39011 6707667; *P. P. pablo.pelegrin@ffis.es; phone, +34 868885038

\section{Author Contributions}

The manuscript was written through contributions of all authors. All authors have given approval to the final version of the manuscript. 'M. C., "C. P. and "H. M.-B. contributed equally to this work.

\section{Notes}

Authors declare no competing financial interest.

\section{Acknowledgment}

We thank M. C. Baños and A. I. Sánchez (IMIB-Arrixaca, Murcia, Spain) for molecular and cellular technical assistance, Prof. L. Lazzarato for assistance in UHPLC-MS experiments, and Dr. Elisa Lupino for assistance in NLRP3 ATPase experiments. This work was supported by Università degli Studi di Torino (Ric. Loc. 2015, and Ric. Loc. 2015 QUOTA B), by grants from Instituto Salud Carlos III-FEDER (PS13/00174 to PP) and European Research Council (ERC-2013-CoG 614578 to PP), Juan de la Cierva postdoctoral fellowship from Ministerio de Economía y Competitividad (FJCI-2014-22041 to DA), Rio Hortega fellowship from Instituto Salud Carlos III (CM14/00008 to HM-B), PP and IH-B would like to acknowledge networking support by the COST Action BM-1406.

\section{Abbreviations Used}

ASC, apoptosis-associated speck-like protein containing a CARD; BAY, BAY 11-7082; BRET, Bioluminescence Resonance Energy Transfer; BSA, bovine serum albumin; CAM, cysteamine; DEX, dexamethasone; DiMF, dimethyl fumarate; HSA, human serum albu- 
min; Keap1, Kelch-like ECH-associated protein 1; LDH, lactate dehydrogenase; LPS, lipopolysaccharide; LRR, leucine-rich repeat domain; MNS,4-methylenedioxy- $\beta$-nitrostyrene; Nrf2, NF-E2-related factor 2; TLR, Toll-like receptor.

\section{REFERENCES}

1) Podolsky, D. K. Inflammatory bowel disease. N. Engl. J. Med. 2002, 347, 417-429.

2) Rogler C. Inflammatory bowel disease cancer risk. Detection and survelliance. Dig. Dis. 2012, 30 (suppl 2), $48-54$.

3) Bauer, C.; Duewell, P.; Mayer, C.; Lehr, H.A.; Fitzgerald, K.A.; Dauer, M.; Tschopp, J.; Endres, S.; Latz, E.; Schnurr, M. Colitis induced in mice with dextran sulfate sodium (DSS) is mediated by the NLRP3 inflammasome. Gut 2010, 59, 11921199.

4) Schmidt, F. I.; Lu, A.; Chen, J. W.; Ruan, J.; Tang, C.; Wu, H.; Ploegh, H. L. A single domain antibody fragment that recognizes the adaptor ASC defines the role of ASC domains in inflammasome assembly. J. Exp. Med. 2016, 213, 771-790.

5) Cai, X.; Chen, J.; Xu, H.; Liu, S.; Jiang, Q. X.; Halfmann, R.; Chen, Z. J. Prion-like polymerization underlies signal transduction in antiviral immune defense and inflammasome activation. Cell 2014, 156, 1207-1222.

6) Lu, A.; Magupalli, V. G.; Ruan, J.; Yin, Q.; Atianand, M. K.; Vos, M. R.; Schröder, G. F.; Fitzgerald, K. A.; Wu, H.; Egelman, E. H. Unified polymerization mechanism for the assembly of ASC-dependent inflammasomes. Cell 2014, 156, 11931206.

7) Jo, E. K.; Kim, J. K.; Shin, D. M.; Sasakawa, C. Molecular mechanisms regulating NLRP3 inflammasome activation. Cell. Mol. Immunol. 2016, 13, 148-159.

8) Prochnicki, T.; Mangan, M.; Latz, E. Recent insight into the molecular mechanisms of the NLRP3 inflammasome activation F1000Research 2016, 5(F1000 Faculty Rev.), 1469 (doi: 10.12688/f1000research.8614.1).

9) Baldwin, A. G.; Brough, D.; Freeman, S. Inhibiting the inflammasome: a chemical perspective. J. Med. Chem. 2016, 59, $1691-1710$.

10) López-Castejón, G.; Pelegrin, P. Current status of inflammasome blockers as anti-inflammatory drugs. Expert Opin. Invest. Drugs 2012, 21, 995-1007.

11) Pellegrini, C.; Antonioli, L.; López-Castejón, G.; Blandizzi, C.; Fornai, M. Canonical and non-canonical activation of NLRP3 inflammasome at the crossroad between immune tolerance and intestinal inflammation. Front. Immunol. 2017, 8, 36.

12) Gustot, T.; Lemmers, A.; Louis, E.; Nicaise, C.; Quertinmont, E.; Belaiche, J.; Roland, S.; Van Gossum, A.; Deviere, J.; Franchimont, D. Profile of soluble cytokine receptors in Crohn's disease. Gut 2005, 54, 488-495.

13) Ludwiczek, O.; Vannier, E.; Borggraefe, I.; Kaser, A.; Siegmund, B.; Dinarello, C. A.; Tilg, H. Imbalance between interleukin-1 agonists and antagonists: relationship to severity of inflammatory bowel disease. Clin. Exp. Immunol. 2004, 138, 323329. 
14) Coccia, M.; Harrison, O. J,; Schiering, C.; Asquith, M. J.; Becher, B.; Powrie, F.; Maloy, K. J. IL-1 $\beta$ mediates chronic intestinal inflammation by promoting the accumulation of IL-17A secreting innate lymphoid cells and CD4(+) Th17 cells. $J$. Exp. Med. 2012, 209, 1595-1609.

15) Villani, A. C.; Lemire, M.; Fortin, G.; Louis, E.; Silverberg, M. S.; Collette, C.; Baba, N.; Libioulle, C.; Belaiche, J.; Bitton, A.; Gaudet, D.; Cohen, A.; Langelier, D.; Fortin, P. R.; Wither, J. E.; Sarfati, M.; Rutgeerts, P.; Rioux, J. D.; Vermeire, S.; Hudson, T. J.; Franchimont, D. Common variants in the NLRP3 region contribute to Crohn's disease susceptibility. Nat. Genet. 2009, 41, 71-76.

16) Perera, A. P.; Kunde, D.; Eri, R. NLRP3 inhibitors as potential therapeutic agents for treatment of inflammatory bowel disease. Curr. Pharm. Des. 2017, 23, 1-7.

17) Liu, W.; Guo, W.; Wub, J.; Luo, Q.; Tao, F.; Gu, Y.; Shen, Y.; Li, J:; Tan, R.; Xu, Q.; Sun, Y. A novel benzo[d]imidazole derivate prevents the development of dextran sulfate sodium-induced murine experimental colitis via inhibition of NLRP3 inflammasome. Biochem. Pharmacol. 2013, 85, 1504-1512.

18) Sun, Y.; Zhao, Y.; Yao, J.; Zhao, L.; Wua, Z.; Wang, Y.; Pan, D.; Miao, H.; Guo, Q.; Lu, N. Wogonoside protects against dextran sulfate sodium-induced experimental colitis in mice by inhibiting NF-kB and NLRP3 inflammasome activation. Biochem. Pharmacol. (Amsterdam, Neth.) 2015, 94, 142-154.

19) Wang, Y.; Wang, H.; Qian, C.; Tang, J.; Zhou, W.; Liu, X.; You, Q.; Hu, R. 3-(2-Oxo-2-phenylethylidene)-2,3,6,7tetrahydro-1H-pyrazino[2,1-a]isoquinolin-4(11bH)-one (compound 1), a novel potent Nrf2/ARE inducer, protects against DSS-induced colitis via inhibiting NLRP3 inflammasome. Biochem. Pharmacol. (Amsterdam, Neth.) 2016, 101, 71-86.

20) Casili, G.; Cordaro, M.; Impellizzeri, D.; Bruschetta, G.; Paterniti, I.; Cuzzocrea, S.; Esposito, E. Dimethyl fumarate reduces inflammatory responses in experimental colitis. J. Crohns Colitis 2016, 10, 472-483.

21) Liu, X.; Zhou, W.; Zhang, X.; Lu, P.; Du, Q.; Tao, L.; Ding, Y.; Wang, Y.; Hu, R. Dimethyl fumarate ameliorates dextran sulfate sodium-induced murine experimental colitis by activating Nrf2 and suppressing NLRP3 inflammasome activation. Biochem. Pharmacol. (Amsterdam, Neth.) 2016, 112, 37-49.

22) Du, X.; Chen, W.; Wang, Y.; Chen, C.; Guo, L.; Ju, R.; Li, J.; Zhang, D.; Zhu, L.; Ye, C. Therapeutic efficacy of carboxyamidotriazole on 2,4,6-trinitrobenzene sulfonic acid-induced colitis model is associated with the inhibition of NLRP3 inflammasome and NF-kB activation. Int. Immunopharmacol. 2017, 45, 16-25.

23) Wang, X.; Wang, S.; Hu, C.; Chen, W.; Shen, Y.; Wu, X.; Sun, Y.; Xu, Q. A new pharmacological effect of levornidazole: inhibition of NLRP3 inflammasome activation. Biochem. Pharmacol. (Amsterdam, Neth.) 2015, 97, 178-188.

24) Mastrocola, R.; Penna, C.; Tullio, F.; Femminò, S.; Nigro, D.; Chiazza, F.; Serpe, L.; Collotta, D.; Alloatti, G.; Cocco, M.; Bertinaria, M.; Pagliaro, P.; Aragno, M.; Collino, M. Pharmacological inhibition of NLRP3 inflammasome attenuates myocardial ischemia/reperfusion injury by activation of RISK and mitochondrial pathways. Oxid. Med. Cell. Longevity 2016, 2016, 11 . 
25) Cocco, M.; Garella, D.; Di Stilo, A.; Borretto, E.; Stevanato, L.; Giorgis, M.; Marini, E.; Fantozzi, R.; Miglio, G.; Bertinaria, M. Electrophilic warhead-based design of compounds preventing NLRP3 inflammasome-dependent pyroptosis. J. Med. Chem. 2014, 57, 10366-10382.

26) Cocco, M.; Miglio, G.; Giorgis, M.; Garella, D.; Marini, E.; Costale, A.; Regazzoni, L.; Vistoli, G.; Orioli, M.; Ra1hane, Massulaha-Ahmed, R.; Detraz-Durieux, I.; Groslambert, M.; Py, B. F.; Bertinaria, M. Design, synthesis, and evaluation of acrylamide derivatives as direct NLRP3 inflammasome inhibitors. ChemMedChem 2016, 11, 1790-1803.

27) Pellegrini, C.; Fornai, M.; Colucci, R.; Lopez-Castejon, G.; Cocco, M.; Garella, D.; Bertinaria, M.; Blandizzi, C.; Antonioli, L. Tu1889 Targeting of NLRP3 inflammasome with a novel selective inhibitor as a suitable strategy for the pharmacological treatment of bowel inflammation. Gastroenterology 2016, 150 (Suppl 1), S968-S969.

28) Juliana, C.; Fernandes-Alnemri, T.; Wu, J.; Datta, P.; Solorzano, L.; Yu, J.-W.; Meng, R.; Quong, A. A.; Latz, E.; Scott, C. P.; Alnemri, E. S. Anti-inflammatory compounds parthenolide and Bay 11-7082 are direct inhibitors of the inflammasome. J. Biol. Chem. 2010, 285, 9792-9802.

29) He, Y.; Varadarajan, S.; Munoz-Planillo, R.; Burberry, A.; Nakamura, Y.; Nunez, G. 3,4-Methylenedioxy- $\beta$-nitrostyrene inhibits NLRP3 inflammasome activation by blocking assembly of the inflammasome. J. Biol. Chem. 2014, 289, $1142-1150$.

30) Regazzoni, L.; Colombo, S.; Mazzolari, A.; Vistoli, G.; Carini, M. Serum albumin as a probe for testing the selectivity of irreversible cysteine protease inhibitors: The case of vinyl sulfones. J. Pharm. Biomed. Anal. 2016, 124, $294-302$.

31) Flanagan, M. E.; Abramite, J. A.; Anderson, D. P.; Aulabaugh, A.; Dahal, U. P.; Gilbert, A. M.; Li, C.; Montgomery, J.; Oppenheimer, S. R.; Ryder, T.; Schuff, B. P.; Uccello, D. P.; Walker, G. S.; Wu, Y.; Brown, M. F.; Chen, J. M.; Hayward, M. M.; Noe, M. C. R.; Obach, S.; Philippe, L.; Shanmugasundaram, V.; Shapiro, M. J.; Starr, J.; Stroh, J.; Che, Y. Chemical and computational methods for the characterization of covalent reactive groups for the prospective design of irreversible inhibitors. J. Med. Chem. 2014, 57, 10072-10079.

32) Duncan, J. A.; Bergstralh, D. T.; Wang, Y.; Willingham, S. B.; Ye, Z.; Zimmermann, A.G.; Ting, J. P. Y. Cryopyrin/NALP3 binds ATP/dATP, is an ATPase, and requires ATP binding to mediate inflammatory signaling. Proc. Natl. Acad. Sci. U.S.A. 2007, 104, 8041-8046.

33) Martín-Sánchez, F.; Diamond, C.; Zeitler, M.; Gomez, A. J.; Baroja-Mazo, A.; Bagnall, J.; Spiller, D.; White, M.; Daniels, M. J. D.; Mortellaro, A.; Peñalver, M.; Paszek, P.; Steringer, J. P.; Nickel, W.; Brough, D.; Pelegrín, P. Inflammasomedependent IL-1 $\beta$ release depends upon membrane permeabilisation. Cell Death Differ. 2016, 3, 1219-1231.

34) Martín-Sánchez, F; Compan, V.; Pelegrin, P. Measuring NLR oligomerization III: detection of NLRP3 complex by bioluminescence resonance energy transfer. In NLR Proteins; Di Virgilio, F. and Pelegrin, P. Eds.; Springer: New York, 2016; pp. 159-168.

35) Baillie, T. A. Targeted covalent inhibitors for drug design. Angew. Chem., Int. Ed. Engl. 2016, 55, 13408-13421.

36) Minekus, M.; Alminger, M.; Alvito, P.; Ballance, S.; Bohn, T.; Bourlieu, C.; Carrière, F.; Boutrou, R.; Corredig, M.; Dupont, D.; Dufour, C.; Egger, L.; Golding, M.; Karakaya, S.; Kirkhus, B.; Le Feunteun, S.; Lesmes, U.; Macierzanka, A.; Mackie, A.; Marze, S.; McClements, D. J.; Ménard, O.; Recio, I.; Santos, C. N.; Singh, R. P.; Vegarud, G. E.; Wickham, M. 
S. J.; Weitschies, W.; Brodkorb A. A standardised static in vitro digestion method suitable for food - an international consensus. Food. Funct. 2014, 5, 1113-1124.

37) Tomas, M.; Beekwilder, J.; Hall, R. D.; Sagdic, O.; Boyacioglu, D.; Capanoglu, E. Industrial processing versus home processing of tomato sauce: effects on phenolics, flavonoids and in vitro bioaccessibility of antioxidants. Food Chem. 2017, $220,51-58$

38) Ruan, L. P.; Chen, S.; Yu, B. Y.; Zhu, D.N.; Cordell, G. A.; Qiu, S. X. Prediction of human absorption of natural compounds by the non-everted rat intestinal sac model. Eur. J. Med. Chem. 2006, 41, 605-610.

39) Luo, Z.; Liu, Y.; Zhao, B.; Tang, M.; Dong, H.; Zhang, L.; Lv, B.; Wei, L. Ex vivo and in situ approaches used to study intestinal absorption. J. Pharmacol. Toxicol. Methods 2013, 68, 208-216.

40) Radi, M.; Dreassi, E.; Brullo, C.; Crespan, E.; Tintori, C.; Bernardo, V.; Valoti, M.; Zamperini, C.; Daigl, H.; Musumeci, F.; Carraro, F.; Naldini, A.; Filippi, I.; Maga, G.; Schenone, S. Botta, M. Design, synthesis, biological activity, and ADME properties of pyrazolo[3,4-d]pyrimidines active in hypoxic human leukemia cells: a lead optimization study. J. Med. Chem. 2011, 54, $2610-2626$.

41) Antoni, L.; Nuding, S.; Wehkamp, J.; Stange, E. F. Intestinal barrier in inflammatory bowel disease. World J. Gastroenterol. 2014, 20, 1165-1179.

42) Antonioli, L.; Fornai, M.; Colucci, R.; Ghisu, N.; Da Settimo, F.; Natale, G.; Kastsiuchenka, O.; Duranti, E.; Virdis, A.; Vassalle, C.; La Motta, C.; Mugnaini, L.; Breschi, M. C.; Blandizzi, C.; Del Taca, M. Inhibition of adenosine deaminase attenuates inflammation in experimental colitis. J. Pharmacol. Exp. Ther. 2007, 322, 435-442.

43) Rahimi, R.; Baghaei, A.; Baeeri, M.; Amin, G.; Shams-Ardekani, M. R.; Khanavi, M.; Abdollahi, M. Promising effect of Magliasa, a traditional Iranian formula, on experimental colitis on the basis of biochemical and cellular findings. World J. Gastroenterol. 2013, 19, 1901-1911.

44) Siegmund, B.; Rieder, F.; Albrich, S.; Wolf, K.; Bidlingmaier, C.; Firestein, G. S.; Boyle, D.; Lehr, H. A.; Loher, F.; Hartmann, G.; Endres, S.; Eigler, A. Adenosine kinase inhibitor GP 515 improves experimental colitis in mice. J. Pharmacol. Exp. Ther. 2001, 296, 99-105.

45) Ardizzone, S.; Bianchi Porro, G. Biologic therapy for inflammatory bowel disease. Drugs 2005, 65, $2253-2286$.

46) Fornai, M.; Antonioli, L.; Pellegrini, C.; Colucci, R.; Sacco, D.; Tirotta, E.; Natale, G.; Bartalucci, A.; Flaibani, M.; Renzulli, C.; Ghelardi, E.; Blandizzi, C.; Scarpignato, C. Small bowel protection against NSAID-injury in rats: effect of rifaximin, a poorly absorbed, GI targeted, antibiotic. Pharmacol. Res. 2016, 104, 186-196.

47) Pellegrini, C.; Fornai, M.; Colucci, R.; Tirotta, E.; Blandini, F.; Levandis, G.; Cerri, S.; Segnani, C.; Ippolito, C.; Bernardini, N.; Cseri, K.; Blandizzi, C.; Haskó, G.; Antonioli, L. Alteration of colonic excitatory tachykininergic motility and enteric inflammation following dopaminergic nigrostriatal neurodegeneration. J. Neuroinflammation 2016, $13,146$.

48) Keating, C.; Pelegrin, P.; Martinez, C. M.; Grundy, D. P2X $\mathrm{X}_{7}$ receptor-dependent intestinal afferent hypersensitivity in a mouse model of postinfectious irritable bowel syndrome. J. Immunol. 2011, 187, 1467-1474. 
49) de Torre-Minguela, C.; Barberà-Cremades, M.; Gómez, A. I.; Martín-Sánchez, F.; Pelegrín, P. Macrophage activation and polarization modify P2X7 receptor secretome influencing the inflammatory process. Sci. Rep. 2016, 6, 22586.

50) Hornung, V.; Bauernfeind, F.; Halle, A.; Samstad, E. O.; Kono, H.; Rock, K. L.; Fitzgerald, K. A.; Latz, E. Silica crystals and aluminum salts activate the NALP3 inflammasome through phagosomal destabilization. Nat. Immunol. 2008, 9, 847856.

51) Barbera-Cremades, M.; Baroja-Mazo, A.; Pelegrin, P. Purinergic signaling during macrophage differentiation results in M2 alternative activated macrophages. J. Leukocyte Biol. 2016, 99, 289-299. 
1

2

3

4

5

6

7

8

9

10

11

12

13

14

15

16

17

18

19

20

21

22

23

24

25

26

27

28

29

30

31

32

33

34

35

36

37

38

39

40

41

42

43

44

45

46

47

48

49

50

51

52

53

54

55

56

57

58

59

60

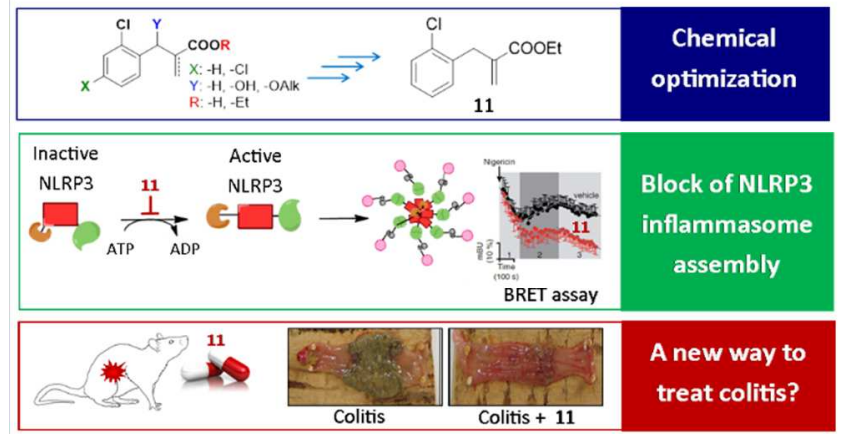

Table of Contents graphic 